\title{
The Role of Auxins and Cytokinins in the Mutualistic Interaction Between Arabidopsis and Piriformospora indica
}

\author{
Jyothilakshmi Vadassery, ${ }^{1}$ Claudia Ritter, ${ }^{1}$ Yvonne Venus, ${ }^{1}$ Iris Camehl, ${ }^{1}$ Ajit Varma, ${ }^{2}$ Bationa Shahollari, \\ Ondr̀ej Novák, ${ }^{3}$ Miroslav Strnad, ${ }^{3}$ Jutta Ludwig-Müller, ${ }^{4}$ and Ralf Oelmüller ${ }^{1}$ \\ ${ }^{1}$ Friedrich-Schiller-Universität Jena, Institut für Allgemeine Botanik und Pflanzenphysiologie, Dornburger Str. 159, \\ 07743 Jena, Germany; ${ }^{2}$ Amity Institute of Herbal and Microbial Studies, Sector 125, Noida 201303, UP, India; ${ }^{3}$ Laboratory \\ of Growth Regulators, Palacky University \& Institute of Experimental Botany AS CR, Slechtitelu 11, 78371 Olomouc, \\ Czech Republic; ${ }^{4}$ Institut für Botanik, Technische Universität Dresden, Zellescher Weg 20b, 01062 Dresden, Germany
}

Submitted 26 March 2008. Accepted 8 July 2008.

\begin{abstract}
Arabidopsis growth and reproduction are stimulated by the endophytic fungus Piriformospora indica. The fungus produces low amounts of auxins, but the auxin levels and the expression of auxin-regulated genes are not altered in colonized roots. Also, mutants with reduced auxin levels (ilr1-1, nit1-3, tfl2, cyp79 b2b3) respond to $P$. indica. However, the fungus rescues the dwarf phenotype of the auxin overproducer sur1-1 by converting free auxin into conjugates, which also results in the downregulation of the auxin-induced IAA6 and the upregulation of the $P$. indica-induced $L R R I$ gene. The fungus produces relatively high levels of cytokinins, and the cytokinin levels are higher in colonized roots compared with the uncolonized controls. trans-Zeatin cytokinin biosynthesis and the CRE1/AHK2 receptor combination are crucial for $P$. indica-mediated growth stimulation, while mutants lacking cis-zeatin, impaired in other cytokinin receptor combinations, or containing reduced cytokinin levels respond to the fungus. Since root colonization is not affected in the cytokinin mutants, we propose that cytokinins are required for $\boldsymbol{P}$. indica-induced growth promotion. Finally, a comparative analysis of the phytohormone mutants allows the conclusion that the response to $P$. indica is independent of the architecture and size of the roots.
\end{abstract}

Additional keywords: plant-microbe interaction, Sebacinaceae.

The endophytic fungus Piriformospora indica, a member of the Sebacinaceae family, colonizes the roots of many plant species including mono- and dicots and mosses, many of which are of forestry, agricultural, horticultural, and medicinal importance (Barazani et al. 2005; Glen et al. 2002; Kaldorf et al. 2005; Oelmüller et al. 2005; Peškan-Berghöfer et al. 2004; Pham et al. 2004; Sahay and Varma 1999; Selosse et al. 2002a and b; Shahollari et al. 2005; 2007; Sherameti et al. 2005, 2008a and b; Urban et al. 2003; Varma et al. 1999, 2001; Waller et al. 2005; Weiss et al. 2004). Root colonization is accompanied by the promotion of growth and higher seed yield, and the plants are more resistant to various biotic and

Corresponding author: Ralf Oelmüller; E-mail: b7oera@uni-jena.de; Telephone: ++49-3641-949231; Fax: ++49-3641-949232.

* The $\boldsymbol{e}$-Xtra logo stands for "electronic extra" and indicates two supplemental figures are published online and Figures 3, 6, and 7 appear in color online. abiotic stresses (Oelmüller et al. 2004; Rai et al. 2004; Sherameti et al. 2008a and b; Varma et al. 2001; Waller et al. 2005). The apparent lack of species specificity suggests that this symbiosis is based on general recognition and signaling processes. We use Arabidopsis thaliana L. as a host for $P$. indica to understand the molecular basis of this interaction. Here, we investigate whether auxins and cytokinins, two phytohormones that are involved in mycorrhizal association (Barker and Tagu 2000; Ludwig-Müller 2000) and many forms of other plantmicrobe interactions (Gonzalez-Rizzo et al. 2006; LudwigMüller 1999; Murray et al. 2007; Siemens et al. 2006; Tirichine et al. 2007) are also involved in the beneficial interactions of plants (Arabidopsis and tobacco) with $P$. indica.

Auxins play an important role in root growth, tropism, apical dominance, and plant senescence and are involved in cell expansion, cell division, and cell differentiation (Davies 2004). In particular, auxins profoundly influence root morphology by inhibiting root elongation, increasing lateral root production, and inducing adventitious roots (Fukaki et al. 2007; LudwigMüller et al. 2005; Rahman et al. 2007). Plants use several tryptophan-dependent and a tryptophan-independent pathway to synthesize auxins (Woodward and Bartel 2005). Auxin levels are also controlled by either conjugation, hydrolysis, or both and by metabolism (Seidel et al. 2006). The hormone rapidly and transiently induces the accumulation of at least three families of transcripts: SMALL-AUXIN-UP RNAs (Gil et al. 1994; Walker and Key 1982), GH3-related transcripts and AUXIN/ INDOLE-3-ACETIC ACID (Aux/IAA) family members (Guilfoyle and Hagen 2007). The GH3 gene family codes for proteins that repress the auxin signal by inactivating the hormone through conjugation (Staswick et al. 2005). Furthermore, the $\mathrm{SCF}^{\mathrm{TIR} 1} \mathrm{E} 3$ ubiquitin ligase complex controls auxin signaling via the toll interleukin 1 receptor family, because it transcriptionally controls degradation of auxin-inducible Aux/ IAA repressors (Quint and Gray 2006, Tan et al. 2007).

Cytokinins are a group of $\mathrm{N}^{6}$-substituted adenine derivatives that affect cell division, vascular development, sink/source relationships, apical dominance, stress tolerance and leaf senescence (Binns 1994; Mok and Mok 2001; Kakimoto 2003; van Rhijn et al. 1997; Werner et al. 2001). Two classes of isopentenyl transferases (IPT) catalyze the first steps in cytokinin biosynthesis (Kakimoto 2001; Miyawaki et al. 2006; Sakakibara 2006; Takei et al. 2001). ATP and ADP IPT are responsible for isopentenyladenine and trans-type zeatin synthesis, and tRNA IPT are required for cis-type zeatin synthesis (Miyawaki et al. 2006). 
trans-Isomers are physiologically active in plants, while ciszeatins (cZ) have been less studied, although they also appear to be active (Suttle and Banowetz 2000; Yonekura-Sakakibara et al. 2004). Cytokinin oxidase and dehydrogenases cleave a side chain (Houba-Herin et al. 1999; Morris et al. 1999; Werner et al. 2006), and a number of enzymes catalyze the conjugation of cytokinins to sugar moieties (Martin et al. 1999a and b, 2001). Models for the cytokinin signaling pathways include the twocomponent systems (Lohrmann and Harter 2002), in which the cytokinin receptors CRE1, AHK2, and AHK3 activate type A response regulators (RR). Further downstream signaling requires histidine phosphotransfer proteins and type B RR, which upregulate some of the type A RR (Hwang and Sheen 2001). Loss-of-function mutants of cytokinin receptors, mainly studied for CRE1, cause a reduced cytokinin sensitivity (Inoue et al. 2001; Ueguchi et al. 2001), although all receptors have partially redundant functions (Higuchi et al. 2004). The AHK2 and AHK3 receptor combination, for example, plays important roles in quantitative control of organs and growth, with opposite regulatory functions in roots and shoots (Riefler et al. 2006). More recently, the central role of cytokinins for rhizobia-induced nodule formation in legumes has been demonstrated for Medicago truncatula and Lotus japonicus (Gonzalez-Rizzo et al. 2006; Murray et al. 2007; Tirichine et al. 2007).

Neither auxins nor cytokinins are able to replace $P$. indica in inducing growth stimulation. We present evidence that the fungus reduces the free auxin level in the roots of the auxin overproducer surl-1 and, thus, stimulates growth and rescues the dwarf phenotype. Furthermore, substantial amounts of cis-cytokinins accumulate in $P$. indica-colonized Arabidopsis roots; however, trans-zeatin (tZ) produced by the plant is essential for growth promotion. Finally, the double-receptor combination $C R E 1 A H K 2$ is necessary for full responsiveness to $P$. indica.

\section{RESULTS}

Auxin and cytokinin levels in $\boldsymbol{P}$. indica cultures.

Full-scan mass spectrometry reveals that $P$. indica hyphae grown in liquid medium produce free IAA (325 pmol per gram of dry weight) and relatively high levels of cytokinins (403 pmol per gram of dry weight) (Fig. 1). We find high levels of isopentenyladenine (iP), an active cytokinin form, cZ, cZ riboside (cZR), and its nucleotide cZ riboside-5'-monophosphate (cZRMP). The high levels of the latter two compounds suggest fast synthesis or turnover. The ratio between $\mathrm{cZ}$ and $\mathrm{tZ}$ is comparable to those in other organisms (Fig. 1).

\section{Auxin and cytokinins}

in $P$. indica-colonized Arabidopsis roots.

Under conditions that promote the growth of Arabidopsis seedlings by the fungus, no significant differences in free and conjugated auxin levels can be detected in uncolonized and colonized roots (Fig. 2A). As expected, younger roots contain higher auxin levels. Interestingly, the level of conjugated auxins increases with increasing age in infected roots, indicating that the fungus may convert some IAA into inactive compounds. In contrast, the cytokinin levels in colonized roots differ from the control (Fig. 2B). While the amounts of $\mathrm{tZ}$, its riboside, and glycoside are comparable, those of the cis forms are 2 (cZ), 6 (cZR), or 10 times (cZ riboside- $O$-glycoside [cZROG]) higher in colonized roots. The amount of cZRMP which is high in fungal hyphae (Fig. 1), is much lower in colonized roots (Fig. 2B), suggesting that it is converted into nonphosphorylated isoforms in symbiotic roots. Finally, iP, the most abundant cytokinin in the hyphae (Fig. 1), is at the detection limit in colonized and uncolonized roots (Fig. 2B). It appears that $\mathrm{cZ}$ cytokinins of fungal origin are metabolized in colonized roots.

\section{Auxin and $P$. indica.}

The mas promoter does not respond to $\mathrm{P}$. indica in tobacco seedlings, although the fungus promotes growth. Some of the best-responding host plants for $P$. indica are Nicotiana spp. $(N$. tabacum [Oelmüller et al. 2005; Sherameti et al. 2005] and $N$. attenuata [Barazani et al. 2005]). Under light-limiting conditions $\left(100 \mu \mathrm{mol} \mathrm{s} \mathrm{m}^{-1}\right)$, a huge difference in growth can be detected between colonized and uncolonized seedlings (Supplementary Fig. S1; Sherameti et al. 2005), and flower devel-

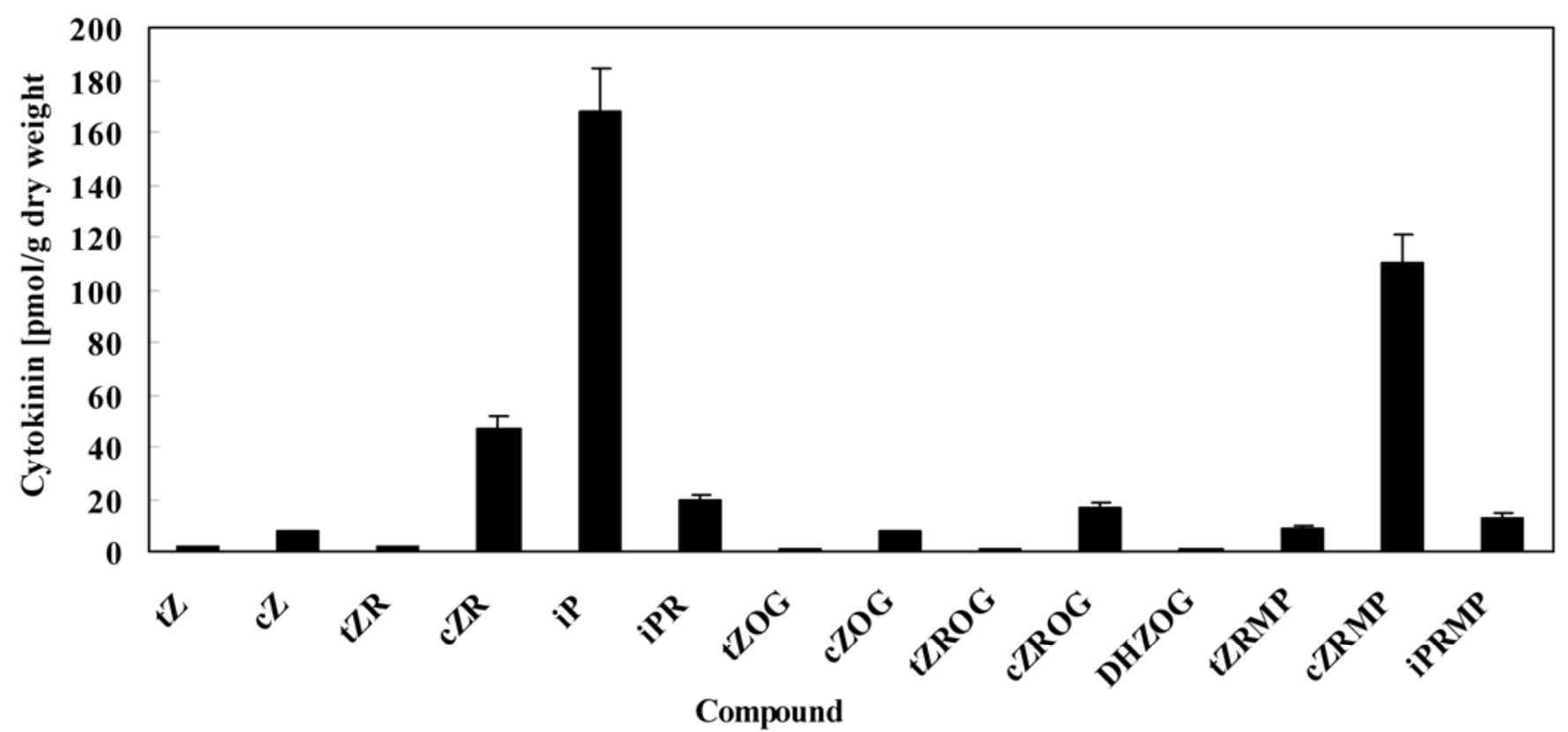

Fig. 1. Endogenous levels of different cytokinins in Piriformospora indica, cultivated in liquid media. $\mathrm{tZ}=$ trans-zeatin; $\mathrm{cZ}=$ cis-zeatin; $\mathrm{tZR}=$ trans-zeatin riboside; $\mathrm{cZR}=$ cis-zeatin riboside; $\mathrm{PP}=$ isopentenyladenine; $\mathrm{iPR}=$ isopentenyladenosine; $\mathrm{tZOG}=$ trans-zeatin- $O$-glucoside; $\mathrm{cZOG}=$ cis-zeatin- $O$-glucoside; tZROG = trans-zeatin riboside- $O$-glucoside; cZROG $=$ cis-zeatin riboside- $O$-glucoside; DHZOG $=$ dihydrozeatin- $O$-glucoside; tZRMP $=$ trans-zeatin riboside-5'-monophosphate; cZRMP = cis-zeatin riboside-5'-monophosphate; iPRMP = isopentenyladenosine-5'-monophosphate. 
opment started approximately 5 weeks earlier in colonized plants. Analysis of 66 plants revealed that colonized plants produce $85 \pm 7 \%$ more seeds. A similar result is obtained with another member of the Sebacinaceae family, Sebacina vermifera (Barazani et al. 2005; $81 \pm 9 \%$ more seeds). However, $\beta$ glucuronidase (GUS) levels in $P$. indica-colonized lines with an uidA gene expressed under the control of the auxin-inducible mannopin synthase (mas) promoter are not increased, either at the seedling level or in adult plants (Table 1). IAA- or 2,4-Dtreated seedlings $(0.2$ to $50 \mu \mathrm{g} / \mathrm{ml})$ contain 20 - and 35 -fold higher GUS levels but do not grow taller than controls (Table 1). Thus, auxin levels of either fungal or plant origin do not increase when $P$. indica promotes growth and seed production in tobacco.

The DR5-GUS reporter system and the vast majority of auxin-responsive genes do not respond to P. indica in Arabidopsis, although the fungus promotes growth. An auxin-responsive element containing a TGTCTC sequence and an adjacent or overlapping coupling element was identified in the auxin-responsive $G H 3$ promoter from soybean (Liu et al. 1994; Ulmasov et al. 1995). The TGTCTC element alone is
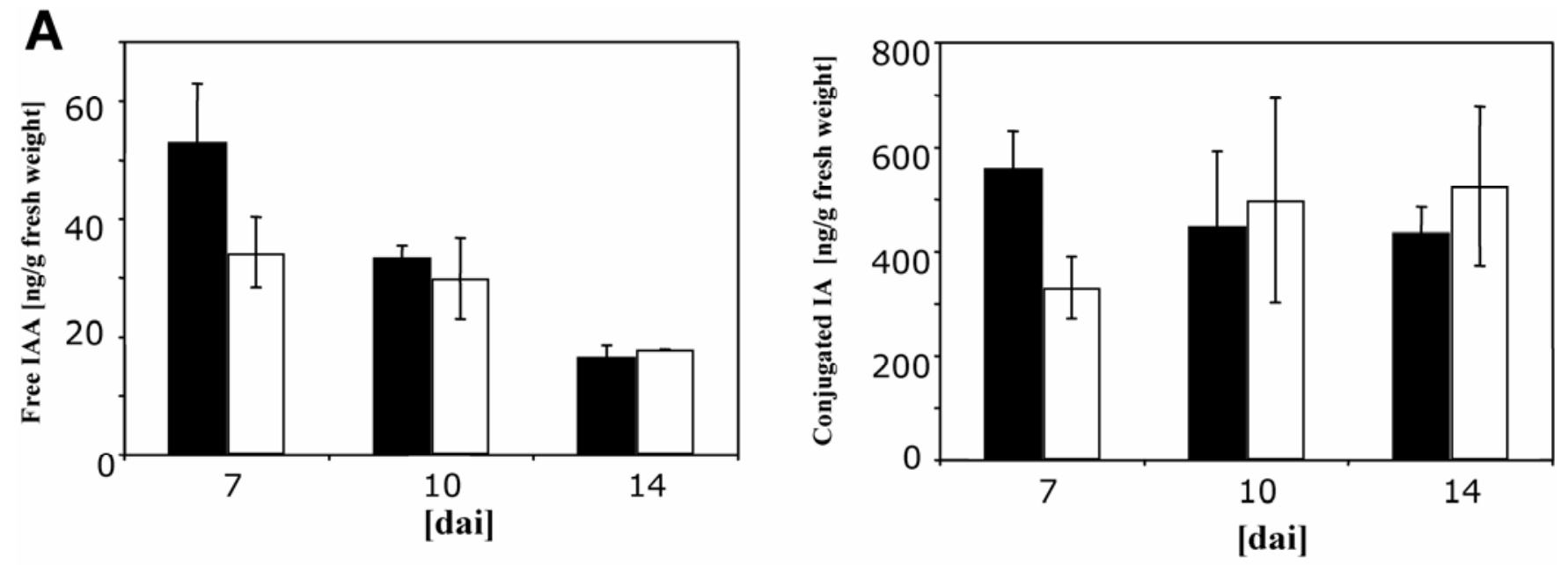

1. $\beta$-glucuronidase (GUS) activity in 20 -day-old roots and shoots of tobacco seedlings with a mas-promoter::uidA gene construct

\begin{tabular}{llrr}
\hline \multirow{2}{*}{ Material } & \multicolumn{2}{c}{ GUS activity (nmol/mg per min) } \\
\cline { 3 - 4 } Seedling & Treatment $^{\mathbf{a}}$ & \multicolumn{1}{c}{ Roots $^{\mathbf{b}}$} & Shoots/leaves $^{\mathbf{b}}$ \\
& LL, control & $0.77 \pm 0.03$ & $0.98 \pm 0.08$ \\
& LL + P. indica & $0.83 \pm 0.06$ & $1.21 \pm 0.14$ \\
& HL, control & $0.98 \pm 0.06$ & $1.13 \pm 0.11$ \\
& HL + P. indica & $1.02 \pm 0.09$ & $1.09 \pm 0.10$ \\
& LL + IAA & $24.36 \pm 2.51$ & $27.47 \pm 2.74$ \\
& LL + 2.4-D & $34.15 \pm 2.85$ & $49.87 \pm 5.17$ \\
Plants & LL, control & $4.14 \pm 0.34$ & $5.32 \pm 0.61$ \\
& LL + P. indica & $3.92 \pm 0.84$ & $5.97 \pm 0.92$ \\
\hline
\end{tabular}

${ }^{a}$ Seedlings were grown in the absence or presence of $P$. indica in either low white light (LL, $100 \mu \mathrm{mol} \mathrm{s}^{-1} \mathrm{~m}^{-2}$ ) or high white light (HL, 600-750 $\mu \mathrm{mol} \mathrm{s} \mathrm{m}^{-1} \mathrm{~m}^{-2}$ ).

${ }^{\mathrm{b}}$ Based on 42 experiments with seven independent primary transformants each, errors represent standard error. Uncolonized seedlings were also treated with indole-3-acetic acid or 2.4-D ( $25 \mu \mathrm{g} / \mathrm{ml})$. The GUS levels for adult plants $(n=66$, either grown in the presence or absence of Piriformospora indica) were determined after 120 days of growth in a temperature- and light-controlled growth chamber, before flowering.

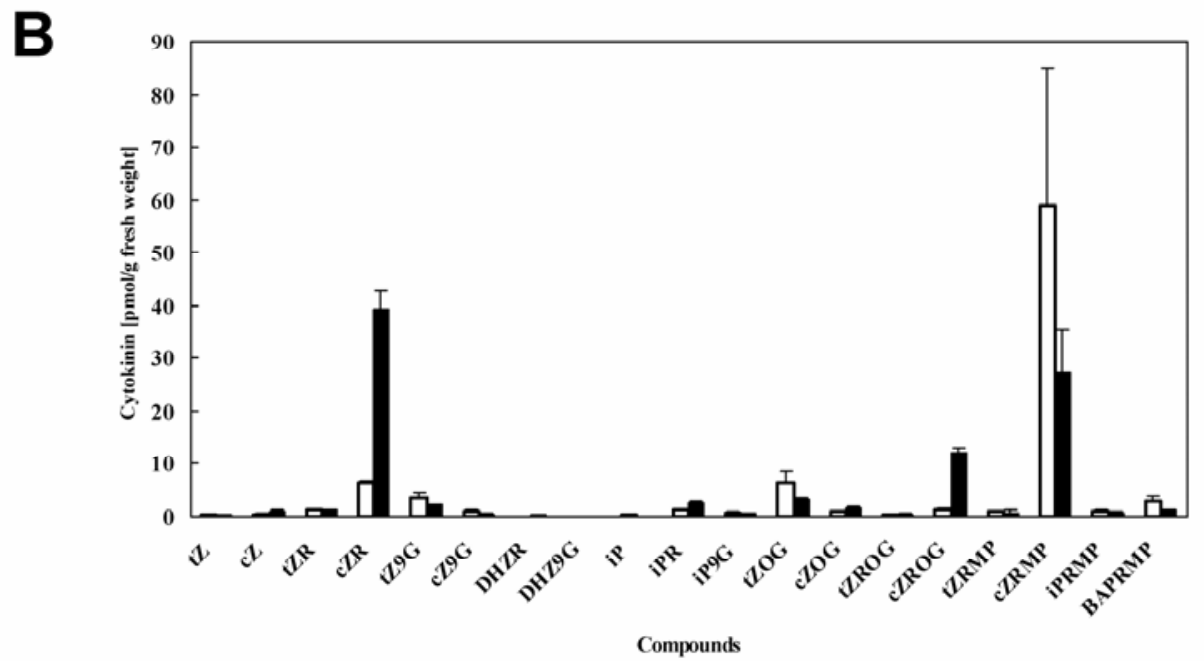

Fig. 2. A, Endogenous levels of free (left) and conjugated (right) indole-3-acetic acid in Arabidopsis roots, which were cocultivated with Piriformospora indica for 7, 10, or 14 days (black bars). Open bars represent the uncolonized control roots of the same age. dai $=$ days after inoculation. Based on three independent experiments, error bars represent standard error. B, Endogenous levels of different cytokinins in Arabidopsis roots, which were cocultivated with $P$. indica for 10 days (black bars) and control roots of the same age (white bars). $\mathrm{tZ}=$ trans-zeatin; $\mathrm{cZ}=$ cis-zeatin; tZR = trans-zeatin riboside; cZR $=$ ciszeatin riboside; $\mathrm{tZ9G}=$ trans-zeatin-9-glucoside; $\mathrm{cZ9G}=$ cis-zeatin-9-glucoside; DHZR = dihydrozeatin riboside; $\mathrm{DHZ9G}=$ dihydrozeatin-9-glucoside; iP = isopentenyladenine; $\mathrm{PRR}=$ isopentenyladenosine; $\mathrm{P} 9 \mathrm{G}=$ isopentenyladenine-9-glucoside; $\mathrm{ZZOG}=$ trans-zeatin- $O$-glucoside; $\mathrm{cZOG}=$ cis-zeatin- $O$-glucoside; tZROG = trans-zeatin riboside- $O$-glucoside; $c Z R O G=$ cis-zeatin riboside- $O$-glucoside; tZRMP = trans-zeatin riboside-5'-monophosphate; cZRMP = cis-zeatin riboside-5'-monophosphate; iPRMP = isopentenyladenosine-5'-monophosphate; BAPRMP = benzylaminopurin riboside-5'-monophosphate. Based on three independent experiments, error bars represent standard error. 
sufficient to confer auxin responsiveness to reporter genes in transgenic Arabidopsis (Ulmasov et al. 1995, 1997). IAA and 2,4-D in concentrations from 0.2 to $50 \mu \mathrm{g}$ per plate stimulate GUS levels between two- $(0.2 \mu \mathrm{g})$ and 25 -fold $(10 \mu \mathrm{g})$ in roots and shoots of DR5::uidA lines, respectively (data not shown), while cocultivation of these seedlings with $P$. indica does not result in higher GUS levels (Table 2). Growth promotion, in contrast, is only observed in the presence of the fungus.

Table 2. $\beta$-glucuronidase (GUS) activities in the shoots and roots of Arabidopsis seedlings with the DR5-GUS reporter gene system ${ }^{\mathrm{a}}$

\begin{tabular}{llcc}
\hline & & \multicolumn{2}{c}{ GUS activity (nmol/mg per min) } \\
\cline { 3 - 4 } Material & \multicolumn{1}{c}{ Treatment } & Roots & Shoots/leaves \\
\hline Seedlings & 6 dai, control & $24.3 \pm 3.3$ & $27.4 \pm 4.1$ \\
& 6 dai + P. indica & $26.1 \pm 5.1$ & $29.2 \pm 3.5$ \\
& 10 dai control & $22.9 \pm 4.1$ & $21.5 \pm 2.9$ \\
& 10 dai + P. indica & $26.4 \pm 4.0$ & $29.2 \pm 3.5$ \\
& 14 dai, control & $28.7 \pm 4.4$ & $78.2 \pm 5.3$ \\
Plants & 14 dai + P. indica & $26.4 \pm 4.0$ & $81.2 \pm 6.5$ \\
On soil & 5 weeks, control & $58.8 \pm 6.1$ & $199.2 \pm 12.3$ \\
& 5 weeks, + P. indica & $61.8 \pm 5.3$ & $191.2 \pm 11.1$ \\
\hline
\end{tabular}

${ }^{a}$ GUS activities 6,10 , and 12 days after inoculation (dai) with Piriformospora indica. Controls $(-P$. indica) were mock-treated. Based on 36 experiments, bars represent standard error. The GUS levels for adult plants were determined 5 weeks after transfer to soil and growth in a temperature- and light-controlled growth chamber, before flowering.
Growth of seedlings in media with up to $10 \mu \mathrm{g}$ of IAA has no effect on growth, while auxin concentrations $>10 \mu \mathrm{g}$ of auxin start to inhibit the growth of the seedlings. Thus, similar to tobacco, it is unlikely that $P$. indica-mediated growth promotion in Arabidopsis is caused by altered auxin levels.

Furthermore, 390 genes have been described in the literature to be either up- or downregulated at least twofold by auxin in Arabidopsis seedlings or shoots (Goda et al. 2004; Liscum and Reed 2002; Sawa et al. 2002; Tian et al. 2002). Analysis of our microarray data uncovered that 154 of them are significantly expressed in roots and that $91 \%$ of the 154 genes do not respond to the fungus (data not shown).

Arabidopsis lines with reduced auxin levels respond to $\mathrm{P}$. indica. Next, we analyzed whether $P$. indica can stimulate growth of knockout lines impaired in different steps of auxin biosynthesis or metabolism (Fig. 3). ilrl-1 has a lesion in the IAA amino acid hydrolase ILR1. This enzyme releases IAA from IAA-leucine and -phenylalanine conjugates (Bartel and Fink 1995). nit 1-3 has a lesion in the nitrilase, so that indole-3acetonitrile cannot be converted to active IAA (Hillebrand et al. 1996). tfl2 has a lesion in a chromodomain protein. Although the role of this protein in auxin metabolism is not clear, the mutant contains reduced IAA and glucosinolate levels (Ludwig-Müller et al. 1999; Bennett et al. 2005). The double mutant cyp 79 b2b3 is defective in two cytochrome P450dependent monooxygenases that catalyze the conversion of
WT

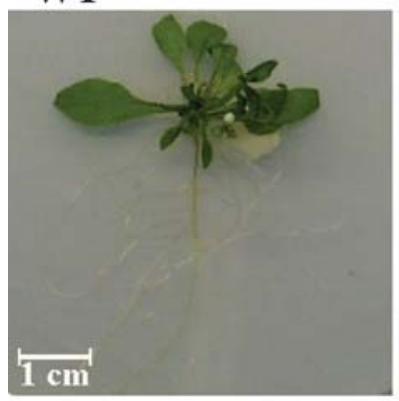

ilr1-1

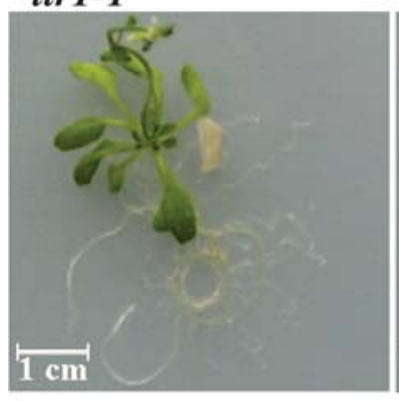

nit1-3

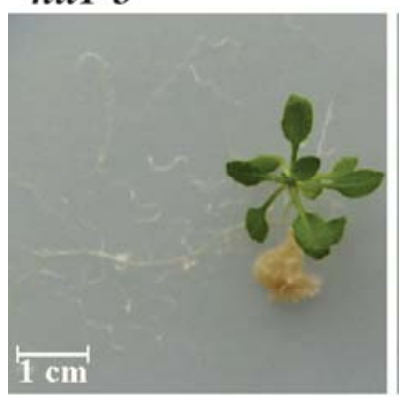

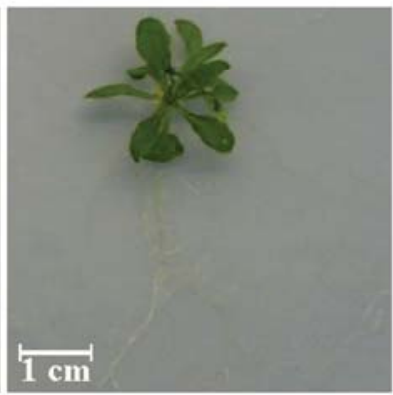
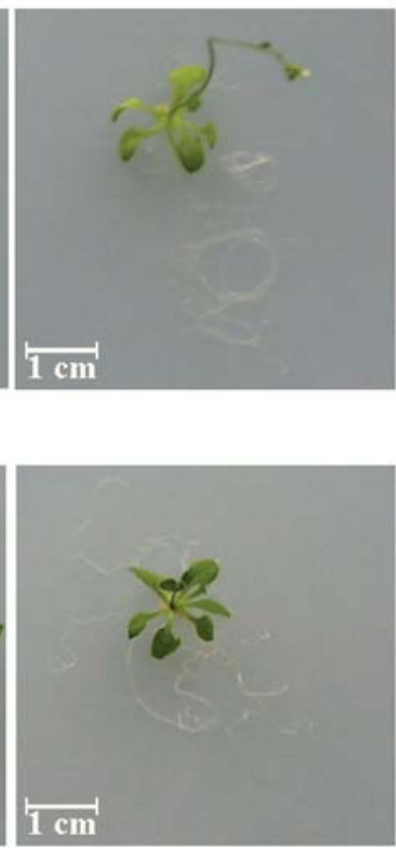

$t f l 2$

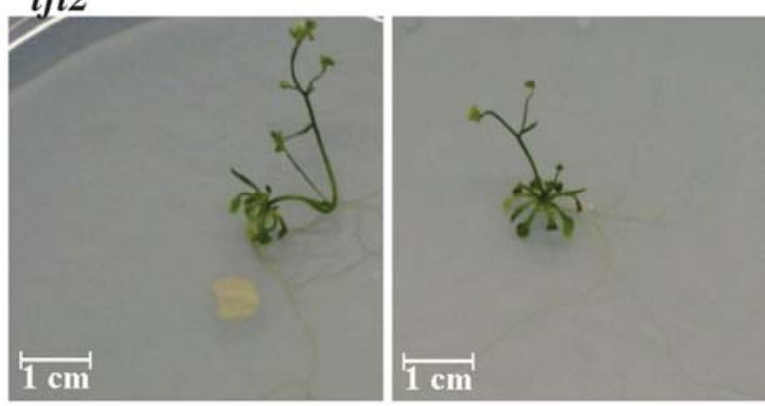

cyp79 b2b3

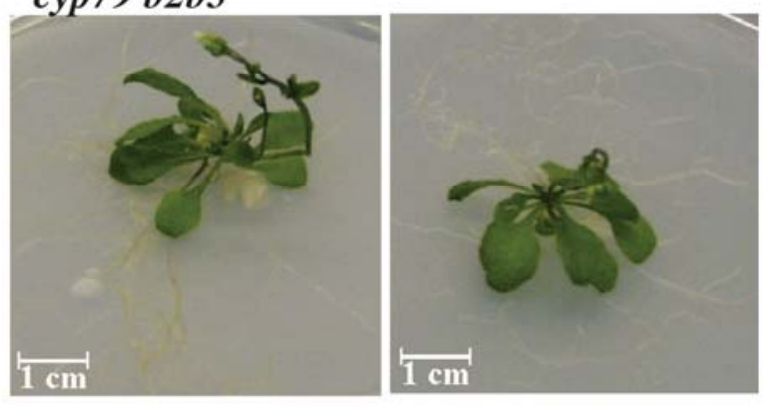

sur1-1

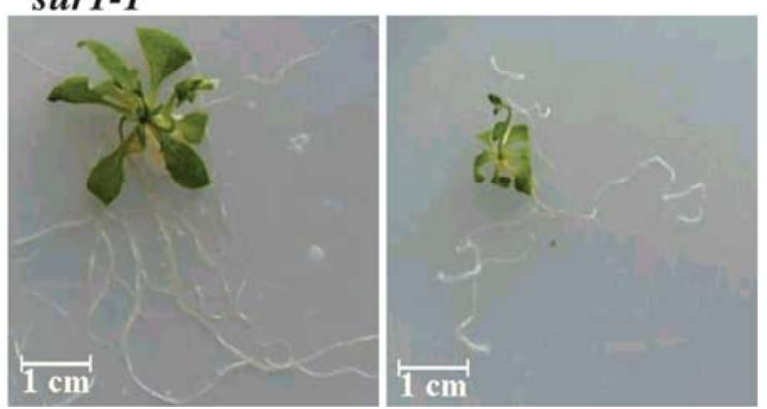

Fig. 3. Arabidopsis seedlings (wild type [WT] and transgenic lines manipulated in their auxin contents) that were grown in the presence (left) or absence (right) of Piriformospora indica for 10 or 15 (for $t f l 2$ ) days. 
tryptophan to indole-3-acetaldoxime. This results in reduced auxin levels in Arabidopsis (Zhao et al. 2002). In spite of substantial differences in the phenotypes and root architectures, all mutant seedlings are taller in the presence of $P$. indica (Fig. 3 ). Cocultivation of the mutant seedlings with $P$. indica for 10 days results in an increase in fresh weight (ilr1-1: $28 \pm 4 \%$, nit1-3: $39 \pm 5 \%$, tfl2: $33 \pm 4 \%$, cyp79 b2b3: $36 \pm 5 \%$, which is in the range of the wild-type control $(34 \pm 3 \%$; data not shown). Thus, reduced auxin levels do not affect the growth response of Arabidopsis seedlings to $P$. indica.

tfl2 has a dwarf phenotype, and the poorly developed roots with only a few lateral roots and small root hairs offer few possibilities for fungal colonization. We barely observe hyphae growing in root cells and never see spores in the cells. Polymerase chain reaction (PCR) analysis for the $P$. indica gene encoding the transcription elongation factor 1 (Pitefl) confirms that colonized $t f l 2$ roots contain severely reduced amounts of fungal DNA and RNA, as compared with the wild type and the ilrl-1 mutant that was used as a control (Fig. 4). This indicates that the extent of root colonization does not correlate with the growth response induced by $P$. indica.

The dwarf phenotype of the auxin overproducer sur1-1 is rescued by the fungus. The surl-1 mutant of Arabidopsis lacks a P450-dependent monooxygenase, which catalyzes the $\mathrm{N}$-oxidation of indole-3-acetaldoxime. This enzymatic reaction is considered to be the step directing the pathway to indole glucosinolates. The mutant accumulates indole-3-acetaldoxime that is converted to active IAA. Thus, sur $1-1$ can be considered as an auxin overproducer (Mikkelsen et al. 2004); the seedlings are much smaller and their root length is approximately half the length of the wild type. Growth of surl-1 seedlings is strongly stimulated by the fungus, and $P$. indica-treated sur $1-1$ seedlings are almost as big as wild-type seedlings cocultivated with the fungus (Fig. 3). In particular, the size, weight, and architecture of the roots $(28.3 \pm 0.9 \mathrm{~cm}$ lateral roots and $5.9 \pm$ $0.3 \mathrm{~cm}$ main root) are indistinguishable from wild-type seedlings grown in the presence of the fungus (Fig. 5A). Growth stimulation of the aerial parts of the seedlings by the fungus indicates an efficient root-shoot communication (Figs. 3 and 5A).

The free auxin level in surl-1 roots 10 days after cocultivation is strongly reduced in $P$. indica-colonized seedlings compared with the uncolonized control (132 \pm 99 vs. $338 \pm 191 \mathrm{ng}$ per gram of fresh weight, respectively), while the conjugated IAA level increases $(6,195 \pm 140$ vs. $3,148 \pm 925 \mathrm{ng}$ per gram of fresh weight, respectively). As a consequence, the IAA6 (At1g52830; Abel et al. 1995) mRNA level, which is upregulated in surl-1 roots and shoots compared with the wild type, is repressed in the presence of the fungus (Fig. 5B). Furthermore, the message level for LRRI (At5g16590), which is upregulated in response to $P$. indica in the wild type and can be used as a marker for a successful recognition of the two symbiotic partners (Shahollari et al. 2007), is much lower in the

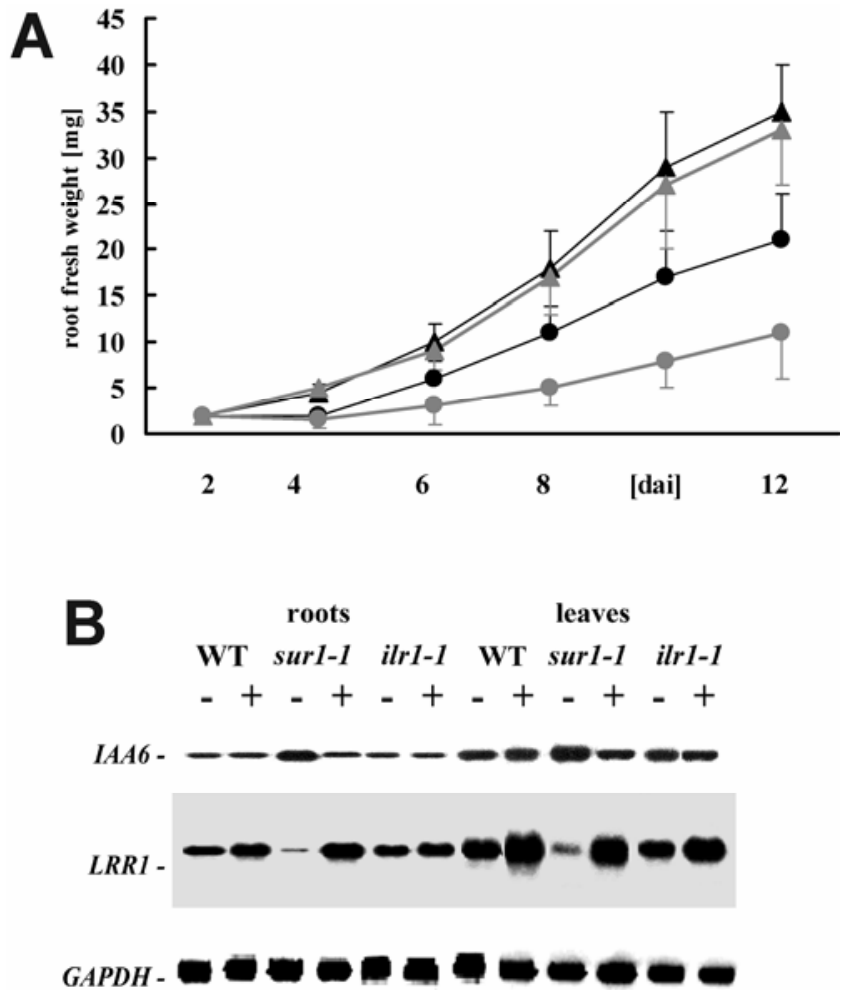

Fig. 5. A, Fresh weight of wild-type (black) and surl-1 (gray) roots that were either mock-treated (dots) or cocultivated with Piriformospora indica (triangles). dai $=$ days after inocculation. Bars represent standard error, based on six independent experiments. B, Northern analysis for IAAC (At1g52830) and LRR1. GAPDH was used as a loading control. Wild-type (WT), sur1-1, and ilr1-1 seedlings were grown in the absence (-) or presence $(+)$ of $P$. indica for 6 days, and RNA was isolated from roots and leaves. Hybridization occurred with IAA6-, LRRI-, and GAPDH-specific gene probes.

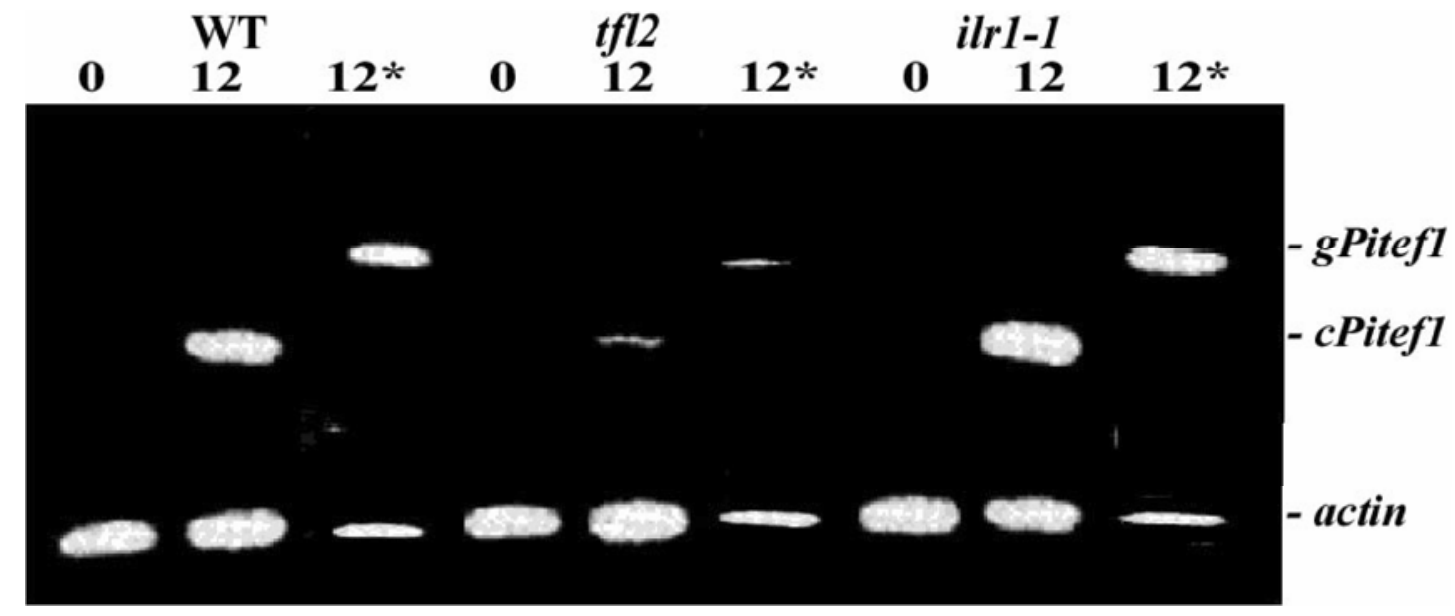

Fig. 4. Comparison of fungal translation elongation factor 1 (cPitefl) mRNA and genomic DNA ( $g$ Pitefl) in roots of wild-type (WT), tfl2, and ilrl-1 seedlings with the plant actin nucleic acids. RNA was isolated from uncolonized (0) roots and roots that were cocultivated with Piriformospora indica for 12 days (12). After reverse transcription, cPitef1 (38 cycles) and actin (24 cycles) were amplified. (12*), genomic DNA was isolated 12 days after cocultivation of the two symbiotic partners and the DNA fragments were amplified. 
surl-1 mutant (Fig. 5B). Cocultivation of surl-1 roots with the fungus results in an almost 10-fold upregulation of the LRRI message, and the level is as high as in colonized wild-type seedlings (Fig. 5B). ilrl-1, which is used as a control for both genes, behaves like the wild type. Strong upregulation of the LRR I mRNA level is also detectable in leaves, demonstrating again the importance of root-shoot communication in $P$. indicacolonized sur $1-1$ seedlings. Together, these results indicate that $P$. indica rescues the dwarf phenotype of sur $1-1$ by reducing the amount and action of free auxin.

\section{Cytokinin and $P$. indica.}

Cytokinin-responsive genes respond to $\mathrm{P}$. indica in Arabidopsis roots. The cytokinin-responsive ARR5 gene is highly expressed in the base of the lateral root primordia and at the root tip during lateral root development of Arabidopsis (Lohar et al. 2004), and the ARR5 mRNA level in $P$. indica-treated roots is $54 \pm 5 \%(n=4)$ higher than in control roots. A similar stimulation $(45 \pm 5 \% ; n=4)$ is obtained for the GUS activity

\section{A}

\section{atipt1 357}
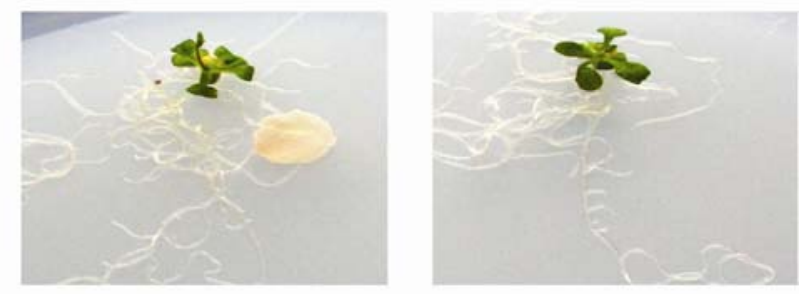

\section{atipt2 9}
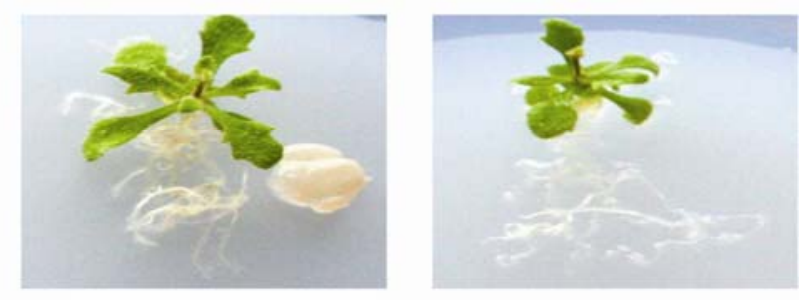

B

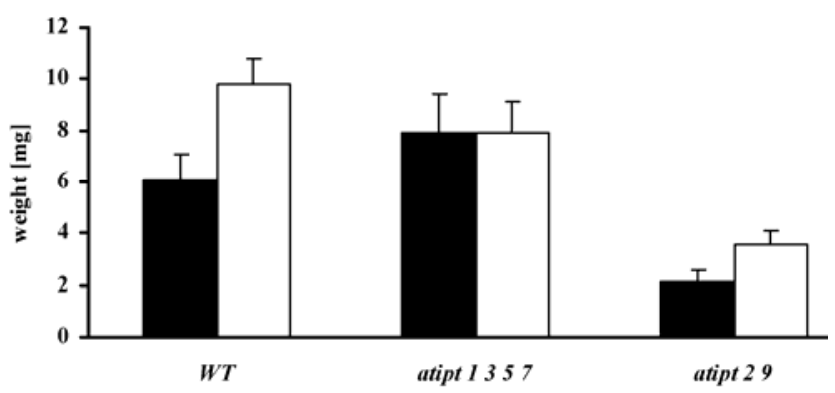

Fig. 6. A, The response of the cytokinin biosynthesis mutants atipt1 atipt 3 atipt5 atipt 7 and atipt 2 atipt 9 to Piriformospora indica. Seedlings were grown in the presence (left) or absence (right) of the fungus for 10 days. To compare the architecture of the roots of the mutants and to determine the root-to-shoot ratio, we also grew the seedlings in liquid MurashigeSkoog medium for 6 days to facilitate optimal root development. Weights were $10.1 \pm 3 \mathrm{mg}$ for atipt 1 atipt 3 atipt 5 atipt 7 and $16 \pm 6 \mathrm{mg}$ for atipt 2 atipt 9 . Root-to-shoot weight ratios were 0.84 for atipt1 atipt 3 atipt 5 atipt 7 and 0.75 for atipt 2 atipt 9 . B, Weight of the roots of 10-day-old wild-type (WT) seedlings and of the cytokinin biosynthesis defective mutants atipt 1 atipt 3 atipt 5 atipt 7 and atipt 2 atipt 9 , grown in the absence (black) or presence (white) of $P$. indica. Based on seven independent experiments. Bars represent standard error. in the roots of transgenic ARR5::uidA lines. Although the stimulation induced by $P$. indica is low compared with the $>20$-fold induction by exogenously applied iP (data not shown), these results prompted us to investigate in greater detail the role of cytokinins in the interaction.

Kiba and associates (2005) presented a list of genes that are regulated in response to cytokinin in Arabidopsis seedlings. Approximately $20 \%$ of them are also expressed in roots, and approximately $35 \%$ showed a low (30 to $80 \%$ ) response to $P$. indica (data not shown). The significance of the response of each gene has been confirmed by other means, and the data are consistent with the results obtained for ARR5, suggesting that cytokinin-regulated genes may play a role in the interaction between $P$. indica and Arabidopsis.

$t Z$ but not $c Z$ biosynthesis in Arabidopsis is required for $\mathrm{P}$. indica-mediated growth promotion. The atipt1 atipt 3 atipt 5 atipt7 quadruple mutant possesses decreased levels of iP, tZtype cytokinins, and their metabolites and slightly increased levels of cZ (Miyawaki et al. 2006). Neither the roots nor the shoots of the atiptl atipt 3 atipt 5 atipt7 seedlings respond to $P$. indica (Fig. 6). In contrast, roots and shoots of the atipt 2 atipt 9 double mutant, which contains reduced levels of iP and cZtype cytokinins, respond to the fungus, comparable to the wild type (Fig. 6). Thus, biosynthesis of tZ- but not cZ-type cytokinins appears to be required for $P$. indica-induced growth promotion in Arabidopsis. Apparently, cZ isomers produced by the fungus cannot replace the missing $\mathrm{tZ}$ isomers in symbiotic roots of the quadruple mutant (discussed below). Furthermore, it is interesting to note that the response to $P$. indica is independent of the organ size. While the aerial parts of the quadruple mutant are relatively small and those of the double mutant comparable to the wild type, the opposite is observed for the roots (Fig. 6).

Table 3 demonstrates that $\mathrm{cZ}$ and $\mathrm{tZ}$ can activate ARR5::uidA gene expression in wild-type roots, although $\mathrm{cZ}$ is less effective than $t Z$. This is consistent with the results obtained by Spíchal and associates (2004). Furthermore, cZR and cZROG, an inactive stable storage form of cytokinin that can be deglycosylated and reversibly converted into cZR, are active in stimulating ARR5::GUS gene expression in roots. Both isomers are synthesized by the fungus and accumulate in colonized roots (Figs. 1 and 2B). One explanation why cZ-cytokinins cannot compensate for the missing $\mathrm{tZ}$-cytokinins in the quadruple mutant can be that the available amount of cZ-cytokinins in colonized roots is too low or not effective enough to stimulate growth in the presence of the fungus. Furthermore, it appears that $\mathrm{cZ}$ cytokinins cannot be converted efficiently to $\mathrm{tZ}$ cytokinins.

The CRE1/AHK2 receptor combination is crucial for $\mathrm{P}$. indica-mediated growth promotion in Arabidopsis. Three cytokinin receptors, CRE1, AHK2, and AHK3, have been described

Table 3. $\beta$-glucuronidase (GUS) activities in the roots and shoots of 20 day-old Arabidopsis seedlings with a ARR5-promoter::uidA gene construct ${ }^{\mathrm{a}}$

\begin{tabular}{lcc}
\hline & \multicolumn{2}{c}{ GUS activity (pmol/g min) } \\
\cline { 2 - 3 } Applied zeatin & Roots & Shoots \\
\hline trans-Zeatin & $1,0839 \pm 1,126$ & $6,267 \pm 372$ \\
cis-Zeatin $(\mathrm{cZ})$ & $5,934 \pm 622$ & $5,502 \pm 372$ \\
cZ riboside & $7,102 \pm 781$ & $4,476 \pm 239$ \\
cZ riboside- $O$-glycoside & $8,189 \pm 914$ & $5,646 \pm 249$ \\
Control & $281 \pm 12$ & $220 \pm 17$ \\
\hline
\end{tabular}

a Seedlings were grown in the absence or presence of the indicated zeatin isomers. Seedlings were grown on Murashige-Skoog medium for 10 days and were transferred to new plates containing $4 \mathrm{nM}$ of the indicated zeatin isomers for an additional 10 days before GUS assay. Based on six independent experiments. 
(Kyozuka 2007). All three receptors are expressed at relatively high levels in roots, but the message levels are not regulated by $P$. indica (relative mRNA levels in roots grown in the absence [-] or presence [+] of $P$. indica for 2 days: CRE1, [-] set as $100 \pm 8 \%,[+] 102 \pm 7 \% ;$ AHK2, [-] $66 \pm 5 \%,[+] 69 \pm 4 \%$; $A H K 3,[-] 67 \pm 4 \%,[+] 59 \pm 6 \% ; n=4)$. Mutations in any of the receptor genes have no effect on the response to $P$. indica (Supplementary Fig. S2; $35 \pm 4 \%$ [crel], $33 \pm 4 \%$ [ahk2], and $31 \pm 5 \%$ [ahk3] increase in fresh weight after cocultivation with the fungus for 10 days). Therefore, double mutants for different receptor combinations are investigated (Fig. 7). The double mutant crel ahk2 shows almost no growth response to $P$. indica. In particular, the roots do not respond to $P$. indica, while some response $(3.2 \pm 0.6 \%)$ is observed for the shoot. The other double mutants crel ahk3 and ahk2 ahk3 respond to the fungus in a manner similar to the wild type (Fig. 7). Growth of the triple mutant is too slow to obtain meaningful results. This indicates that the CRE1 AHK2 receptor combination is crucial for response to $P$. indica.

The cytokinin oxidase and dehydrogenase overproducers 35S::AtCKX1 and 35S::AtCKX2 show reduced cytokinin levels due to an increased cytokinin degradation. The lines have stunted and bushy shoots and their roots are bigger than the wild type (Werner et al. 2003). Growth of both overproducers is clearly promoted by $P$. indica. After 10 days of cocultivation, a $37 \pm 4 \%$ increase in the fresh weight is detectable, which is comparable to the wild type $(34 \pm 3 \%)$. This indicates that the reduced levels of cytokinins in $35 \mathrm{~S}:: C K X 1$ and $35 \mathrm{~S}:: C K X 2$ and the different root architectures do not affect response to $P$. indica.

Regulation of $\mathrm{P}$. indica-responsive genes in atipt 1 atipt 3 atipt5 atipt 7 and cre 1 ahk 2 and colonization of their roots. The importance of $\mathrm{tZ}$ biosynthesis and the CRE1 AHK2 receptor combination for the beneficial interaction between the two symbiotic partners is further supported by the observation that the message levels for LRRl and germin, two genes that are upregulated in wild-type roots in the response of $P$. indica, are not upregulated in colonized roots of the two mutants (Fig. 8). While the LRRI mRNA level is comparable to the level in uncolonized wild-type seedlings, that of germin is reduced. The $P$. indica-responsive cZ mutant atipt 2 atipt 9 and the double receptor mutant $a h k 2$ ahk3 were used as controls. For both mutants, the mRNA levels are upregulated in the roots in response to $P$. indica, comparable to the wild type (Fig. 8). Finally, this is not caused by differences in the root colonization. A comparative PCR analysis of the Pitiefl mRNA levels relative to the root actin gene (Fig. 4) shows that the ratios do not differ significantly from the wild type. If the wild-type ratio after 12 days of cocultivation is set as $1.00 \pm 0.13$, that for atipt 1 atipt 3 atipt 5 atipt 7 is $1.09 \pm 0.15$ and that for cre 1 ahk 2 is $0.96 \pm 0.17$ (controls: tfl2: $0.08 \pm 0.01$ [Fig. 4], atip2 atip9: $0.94 \pm 0.16$, ahk2 ahk3: $1.07 \pm 0.10$; data based on four independent experiments, errors are standard error).

Root and shoot architecture and growth promotion. The architecture, weight, and branching of the roots, as well as the root-to-shoot fresh-weight ratios (RSFWR) of the cytokinin mutants do not correlate with their response to $P$. indica. For instance, the phenotypes of atip1 atip3 atip5 atip7 and ahk2 ahk3 are similar under our growth conditions, and both mutants have smaller shoots and longer roots than the wild type (Miyawaki et al 2006; Riefler et al 2006). Atipl atip3 atip5 atip7 does not respond to $P$. indica (Fig. 6), while ahk2 ahk3 does. Also, atipt2 atip 9 has a reduced root growth, but its response to $P$. indica is comparable to that of the wild type
A
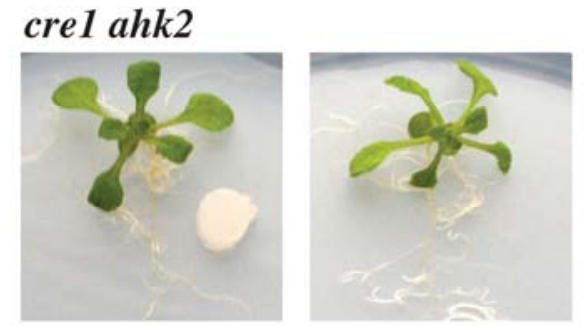

cre1 ahk3
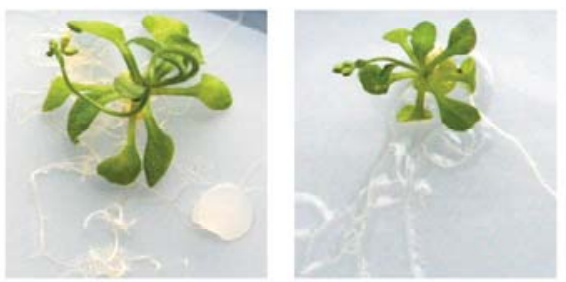

ahk2 ahk3

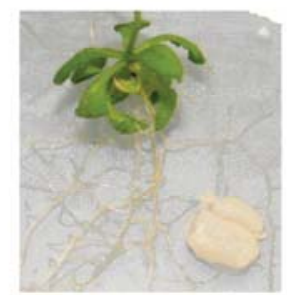

B

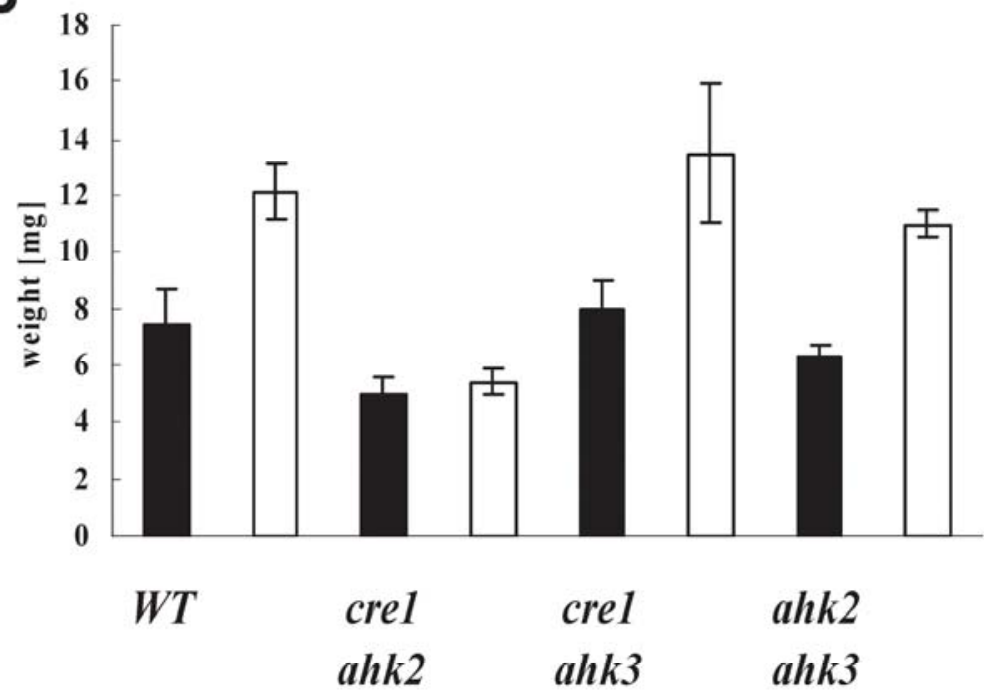

Fig. 7. A, Combinations of cytokinin-receptor double-mutants (ahk2, ahk3, and cre1) were grown in the presence (left) or absence (right) of Piriformospora indica for 10 days. To compare the architecture of the roots of the receptor mutants and to determine the root-to-shoot ratio, seedlings were grown in liquid Murashige-Skoog medium for 6 days to facilitate optimal root development. Weights were $11.2 \pm 3 \mathrm{mg}$ for $\mathrm{cre} 1 \mathrm{ahk} 2,19.6 \pm 3 \mathrm{mg}$ for $\mathrm{cre} 1 \mathrm{ahk} 3 \mathrm{and} 7.0 \pm$ $2.0 \mathrm{mg}$ for $a h k 2$ ahk3. Root-to-shoot weight ratios were 0.20 for $c r e 1$ ahk2, 0.28 for $c r e 1$ ahk3 and 0.74 for $a h k 2$ ahk3. B, Weight of the roots of wild-type (WT) seedlings as well as double knockout lines, grown in the absence (black) or presence (white) of $P$. indica for 10 days. Based on seven independent experiments. Bars represent standard error. 
(Fig. 6). Furthermore, ahk3 ahk2 and atipt2 atip9 have RSFWR of 0.74 and 0.75 , respectively, although their response to $P$. indica is comparable to that of the wild type $(\mathrm{RSFWR}=$ 0.23). crel ahk2 has a RSFWR of 0.20 , which is comparable to that of the wild type and quite different from that of atip1 atip3 atip5 atip7 (RSFWR = 0.84); however, neither mutant responds to $P$. indica. These examples demonstrate that the size, weight, and RSFWR of the cytokinin mutants have little effect on the response to $P$. indica.

\section{DISCUSSION}

The involvement of auxin and cytokinin in plant-microbe interactions has been widely studied (Barker and Tagu 2000; Cooper and Long 1994; Fitze et al. 2005; Gonzalez-Rizzo et al. 2006; Herrmann et al. 2004; Lohar et al. 2004; Murray et al. 2007; Oldroyd 2007; Reddy et al. 2006; Sirrenberg et al. 2007; Tirichine et al. 2007); however, relatively little is known about their involvement in the interactions between plants and endophytic fungi. Here, we use well-characterized Arabidopsis mutants as well as molecular and biochemical tools to understand the role of these two hormones in the beneficial interaction with $P$. indica.

The role of auxin in the Arabidopsis-P. indica interaction.

Mutants with reduced auxin levels respond to $P$. indica and the auxin levels and the expression of auxin-regulated genes in Arabidopsis and tobacco roots do not change when the fungus promotes plant growth. The expression of auxin-responsive promoter::uidA constructs is also not stimulated after transfer of the seedlings to soil for several months, although beneficial effects can clearly be seen under these conditions. Although the auxin concentrations that stimulate growth can differ substantially from those that activate the expression of auxinresponsive genes, none of the auxin concentrations that were tested in our system stimulated growth and, at concentrations higher than $10 \mu \mathrm{g}$ per plate, even inhibited growth of Arabidopsis seedlings. Thus, we propose that the auxin levels in seedlings and adult plants have little or no effect on $P$. indicamediated growth promotion and stimulation of productivity in adult plants.

In contrast, the auxin overproducer surl-1 responds more sensitively to $P$. indica than to the wild type, and its dwarf phenotype is almost rescued in the presence of the fungus. To our knowledge, surl-1 shows the strongest response of a plant to an endophytic fungus reported so far. $P$. indica reduces the free auxin levels in the roots, and consequently, the expression of the auxin-upregulated IAA6 mRNA level is downregulated and the $P$. indica-induced LRRI mRNA upregulated in both roots and shoots of colonized surl-1 seedlings (Fig. 5). The approximately twofold decrease in the free auxin level in colonized roots can be partially explained by the fact that these roots are approximately twice as large as the uncolonized control and thus in a different developmental stage (Fig. 5). However, the conjugated auxin levels do not change significantly in response to the fungus between days 7 and 14 in the wild type (Fig. 2A), while the level is doubled in colonized surl-1 roots compared with the uncolonized control. These results demonstrate that the fungus interferes with the auxin metabolism in surl-1. It remains to be determined whether $P$. indica directly influences the auxin levels or whether they are manipulated by the plant as a consequence of the growth response to the fungus.

\section{The role of cytokinins \\ in the Arabidopsis-P. indica interaction.}

Many root-associated microorganisms produce cytokinin, and plants possessing mycorrhiza accumulate high concentrations of iP-like compounds in roots and shoots. Differences between mycorrhizal and nonmycorrhizal plants in total ZRlike compounds have also been reported (Ginzberg et al. 1998; van Rhijn et al. 1997). Nod-factor signaling by rhizobia in the legume Lotus japonicus requires the cytokinin-receptor LHK1 for cell division and initiation of nitrogen-fixing nodule development (Murray et al. 2007; Tirichine et al. 2007). LHK1 is critical for nodule organogenesis, but bacterial entry through infection thread formation is independent of cytokinin signaling. Several lines of evidence support the idea that cytokinins also play a role in the beneficial interaction between $P$. indica and Arabidopsis. i) Cytokinin- but not auxin-responsive genes are differentially regulated in $P$. indica-colonized Arabidopsis roots. ii) The CRE1/AHK2 receptor combination is crucial for the response to $P$. indica. Riefler and associates (2006) also analyzed cytokinin receptor mutants and found that the $a h k 2$ ahk3 double mutant develops a strongly enhanced root system through faster growth of the primary root and more branching. The dry weight of these roots increases more than twofold as compared with the wild type, while the enhancement of the other double-mutant combinations was in the order of $20 \%$. The response of the ahk2 ahk3 mutant to $P$. indica may be explained by the larger root morphology, although we do not see a direct correlation between root size and the growth response to $P$. indica (discussed below). The absence of the

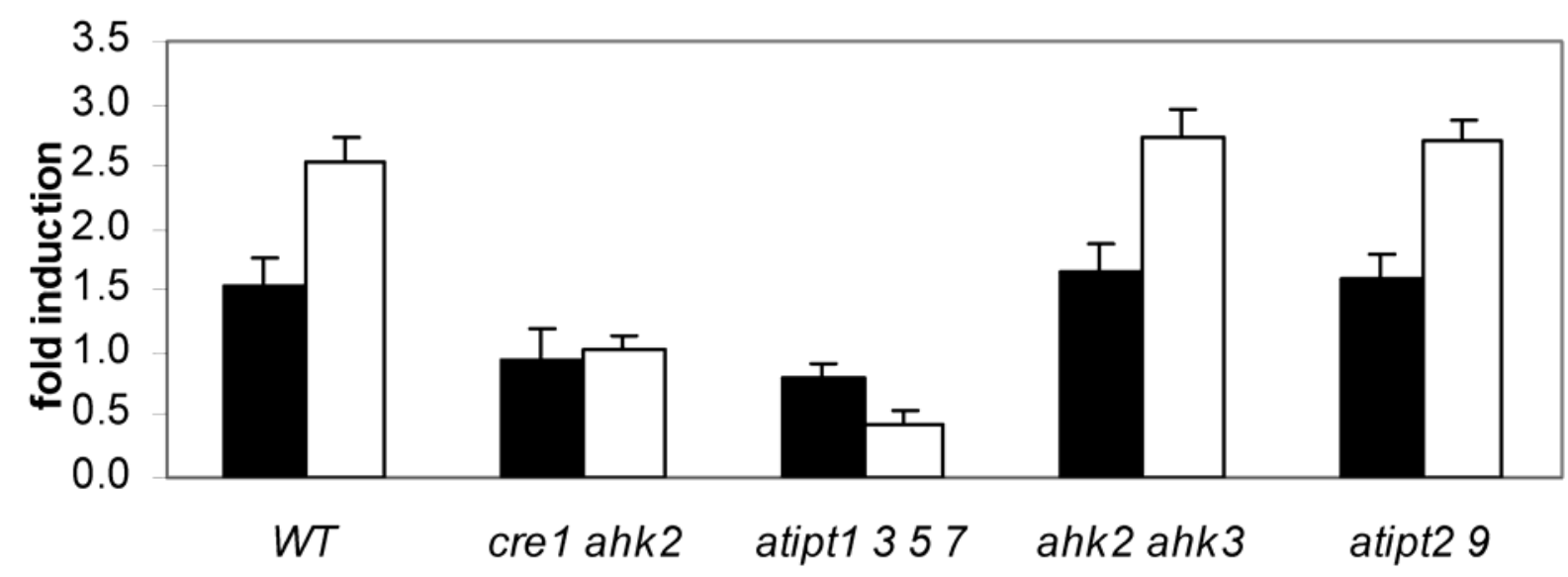

Fig. 8. Change of the mRNA levels for LRRI (black) and germin (white) in the presence of Piriformospora indica in Arabidopsis roots. Wild-type (WT), cre1 ahk2, and atipt1 atipt3 atipt 5 atipt 7 seedlings were cocultivated with or without $P$. indica for 6 days, and the amount of LRR1 and germin mRNA was determined by real-time polymerase chain reaction relative to the GAPDH control. The ratios shown are the mRNA levels in colonized roots to uncolonized control. Bars represent standard error. 
response of the cre 1 ahk2 mutant to the fungus defines a new role of this receptor combination. However, besides CRE1 and AHK2, other receptors must exist in the root that perceive signals from $P$. indica. For instance, $P$. indica induces a rapid increase in the intracellular calcium level in root cells, and this response occurs also in the cre 1 ahk2 mutant (data not shown). iii) $P$. indica itself produces $\mathrm{iP}$ and cZ-type cytokinins, and elevated levels of these isomers accumulate in colonized roots. Although both isomers are able to stimulate ARR5 gene expression in the roots, we could not demonstrate a specific effect of $\mathrm{cZ}$ isomers on growth promotion. However, our data clearly demonstrate that $\mathrm{tZ}$ is required for the beneficial interaction. This suggests that $\mathrm{cZ}$ cytokinins are either not or not efficiently converted to $\mathrm{tZ}$ cytokinins, although a cis-trans isomerase has been identified in Phaseolus spp. (Bassil et al. 1993). Alternatively, the available amount of cZ of either fungal or plant origin in the quadruple mutant is too low or not effective enough to stimulate growth in the symbiosis. It is known that $\mathrm{cZ}$ is less effective than $\mathrm{tZ}$ in activating the cytokinin receptors, both in yeast and in planta (Inoue et al. 2001; Spichal et al. 2004), which is consistent with our data on ARR5 regulation in roots (Table 3 ). Another reason for the lack of a response to $\mathrm{cZ}$ can be that enzymatic activities deriving from one of the four inactivated genes in the quadruple mutant, atipt 1, atipt3, atipt5, or atipt 7, may be required for the beneficial interaction. Finally, the dwarf phenotype of the aerial part of the quadruple mutant may be responsible for the lack of the response, although this appears to be unlikely, since the aerial parts of the ahk2 ahk3 receptor mutant have a similar phenotype and respond to the fungus. Furthermore, the roots of the quadruple mutant resemble those of the wild type, although their growth is not stimulated by $P$. indica.

\section{Auxin and cytokinin action and ratio in the Arabidopsis- $P$. indica interaction.}

Colonization of the sur 1-1, crel ahk2 and quadruple mutant roots is comparable to that of the wild type, suggesting that recognition of the two symbiotic partners is independent of the phytohormones. We propose that downstream processes such as initiation of either cell division, elongation, or both may require the phytohormones. For instance, $P$. indica-induced growth stimulation of surl-1 roots is accompanied by an increase in the DNA content (data not shown), which supports the idea that the fungus induces cell division in the mutant. Thus, it is not surprising that the levels of the growth-regulating phytohormones are altered by the fungus. It can also be important to manipulate the auxin to cytokinin ratio, in particular in sur1-1, when the ratio does not support growth stimulation. One possibility can be the conversion of free auxin into inactive conjugates. Since both root and shoot growth is promoted by $P$. indica, it is likely that the fungus exerts different effects on the phytohormones or their ratios, or both, in the two organs.

\section{$P$. indica-mediated growth promotion is independent of the root architecture.}

Many of the mutants analyzed in this study have root architectures, lengths, or root to shoot ratios, which differ substantially from the wild type. For instance, ahk2 ahk3 has long roots relative to the aerial parts (Riefler et al. 2006; Fig. 7), the $35 S:: C K X 1$ and $35 S:: C K X 2$ lines have stunted and bushy roots (Werner et al. 2003), the sur1-1 roots are approximately half as long as the wild type (Fig. 5), and $t f l 2$, in addition to its dwarf phenotype, with fewer lateral roots and shorter root hairs, contains a greatly reduced root surface (Bennett et al. 2005). All of these mutants respond to $P$. indica, suggesting that the root size and architecture have little effect on the growth response induced by the fungus. This is further supported by the comparative analysis of the cytokinin receptor double mutants. The ahk2 ahk3 mutant has an increased root system, while that of the other combinations are comparable to the wild type. However, cerl $a h k 2$ fails to respond to $P$. indica, while the other mutant combinations do. Analysis of $t f l 2$ also demonstrates that the reduced root colonization does not lead to a reduced growth response to the fungus. Taken together, it appears that the size and architecture of the roots and its colonization does not correlate with the growth response induced by $P$. indica.

\section{MATERIALS AND METHODS}

Seed material, growth, and cocultivation experiments.

Wild-type, mutant, or transgenic Arabidopsis thaliana or Nicotiana tabacum seeds were surface-sterilized and cocultivated with $P$. indica, as described in Sherameti and associates (2008a and b). For cocultivation, 7-day-old A. thaliana and 14day-old Nicotiana tabacum seedlings were used. After surfacesterilization, the seeds were placed on petri dishes containing Murashige-Skoog nutrient medium (Murashige and Skoog 1962). After cold treatment at $4^{\circ} \mathrm{C}$ for $48 \mathrm{~h}$, plates were incubated for 7 days at $22^{\circ} \mathrm{C}$ under continuous illumination (100 $\mu \mathrm{mol} \mathrm{m} \mathrm{m}^{-2} \mathrm{~s}^{-1}$ ) to allow growth of the seedlings without $P$. indica. P. indica was cultured as described previously (Verma et al. 1998; Peškan-Berghöfer et al. 2004) on Aspergillus minimal medium (Kaldorf et al. 2005). Nine days after the beginning of the experiments, A. thaliana seedlings were transferred to nylon disks (mesh size $70 \mu \mathrm{m}$ ) and were placed on top of a modified PNM culture medium $\left(5 \mathrm{mM} \mathrm{KNO}_{3}, 2 \mathrm{mM} \mathrm{MgSO}\right.$, $2 \mathrm{mM} \mathrm{Ca}\left(\mathrm{NO}_{3}\right)_{2}, 0.01 \mu \mathrm{M} \mathrm{FeSO}, 70 \mu \mathrm{M} \mathrm{H} \mathrm{BO}_{3}, 14 \mu \mathrm{M}$ $\mathrm{MnCl}_{2}, 0.5 \mu \mathrm{M} \mathrm{CuSO}_{4}, 1 \mu \mathrm{M} \mathrm{ZnSO}_{4}, 0.2 \mu \mathrm{M} \mathrm{Na}_{2} \mathrm{MoO}_{4}, 0.01$ $\mu \mathrm{M} \mathrm{CoCl}_{2}, 10.5 \mathrm{~g}$ of agar per liter, $\mathrm{pH}$ 5.6) in petri dishes. One seedling was used per dish. After $24 \mathrm{~h}$, fungal plugs of $5 \mathrm{~mm}$ in diameter were placed at a distance of $1 \mathrm{~cm}$ from the roots. The uninfected control plants received the same plugs without the fungus. The petri dishes were incubated at $22^{\circ} \mathrm{C}$ under continuous illumination from the side $\left(80 \mu \mathrm{mol} \mathrm{m} \mathrm{m}^{-2} \mathrm{~s}^{-1}\right)$ and were normally assayed 10 days after cocultivation, if not otherwise stated. Fresh weights were determined directly after seedlings (roots and shoots separately) were harvested. One experiment consisted of 80 infected and 80 uninfected seedlings, and this was repeated four times, if no other information is given. The following mutants and transgenic lines were used for the experiments: tobacco plants containing the mas promoter fused to uidA (Comai et al. 1990), Arabidopsis: ilr1-1 (Bartel and Fink 1995), nitl-3 (Hillebrand et al. 1996), surl-1 (Mikkelsen et al. 2004), cyp79 b2b3 (Zhao et al. 2002), tfl2 (Bennett et al. 2005), cryl (Moon et al. 2003), 35S-AtCKX1, and 35SAtCKX2 (Werner et al. 2003), cre1, ahk2, ahk3, ahk2 cre1 double, ahk3 cre1 double, ahk2 ahk3 double mutants (Nishimura et al. 2004), atipt 1 atipt 3 atipt 5 atipt 7 quadruple mutant, atipt 2 atipt9 double mutant (Miyawaki et al. 2006).

\section{GUS activity.}

For GUS expression studies, transgenic lines with the auxinresponsive $D R 5$ promoter (Ulmasov et al. 1995, 1997) and the cytokinin-responsive ARR5 promoter (Brandstatter and Kiefer 1998) were used. GUS assays were described earlier (Sherameti et al. 2002). The system of reference was an equal amount of fresh weight.

\section{Reverse transcription (RT) and real time PCR and Northern analyses.}

Real-time quantitative RT-PCR was described in Pfalz and associates (2006). The following primer pairs were used: ARR5: GAGCTGACTACGTTGTTGAG and GGAGACAATG 
TCAAGGTCGG; germin (At5g38910): CTTCGGACCCAAG CTCTCTTCAG and CAAGACCTCGGAGGCACGTGGGT; the mRNA for a $P$. indica-inducible leucine-rich repeat transmembrane protein called LRR1 (Shahollari et al. 2007): CGGCGAGTTTGATCTTGATGG and CTCAGGAACCACG ACATCTCTC. Piriformospora indica was monitored with a primer pair for the elongation factor 1 (Pitefl; Bütehorn et al. 2000): ACCGTCTTGGGGTTGTATCC and CGTCGCTGTC AACAAGATG. The gene for the cytosolic glycerinaldehyde3-phosphate dehydrogenase (At3g04120) served as control: GAGCTGACTACGTTGTTGAG and GGAGACAATGTCAA GGTCGG.

For Northern blot analyses, gene-specific primers were designed to amply cDNA fragments from our cDNA library (Sherameti et al. 2004). The primers were designed such that they amplify the entire coding region including four nucleotides up- and downstream of the genes. Northern analysis was performed with gel-purified, labeled PCR products (Shahollari et al. 2007).

\section{Microarrays.}

Arabidopsis seedlings, grown as described above, were cocultivated (or mock-treated with an agar plug without the fungus) with $P$. indica for 2, 3, and 6 days. RNA was extracted from $70 \mathrm{mg}$ of root materials with the RNeasy plant mini kit, followed by an On-Column DNAse treatment (Qiagen, Hilden, Germany). Microarray hybridization was performed with the Arabidopsis genome array ATH1 from Affymetrix, and the data were analyzed with the GCOS1.4 software. Three independent RNAs per timepoint were used for the hybridizations, and means of the three signals were taken for further analysis. The data were screened for those genes that have been reported to be regulated by auxins (Goda et al. 2004; Liscum and Reed 2002; Sawa et al. 2002; Tian et al. 2002) or cytokinins (Kiba et al. 2005). Those genes that showed a significant expression in roots according to the GCOS1.4 software were further analyzed for their response to $P$. indica. A gene was considered to be regulated by phytohormones and $P$. indica, if it responds to the fungus at all three timepoints.

\section{IAA analysis.}

Approximately $1.5 \mathrm{~g}$ of fungal material was used for auxin analysis from cultures of $P$. indica grown 4 weeks in liquid medium in the dark. For the analysis of IAA in roots, $100 \mu \mathrm{g}$ of root material was used, and all experiments were performed in triplicates, and results given are averages of the three assays. Free IAA was extracted using isopropanol; $\mathrm{H}_{2} \mathrm{O}$ (70:30, $\mathrm{vol} / \mathrm{vol}$ ), the resulting extract, was centrifuged, and then, the supernatant was evaporated to the aqueous phase, using a rotary evaporator (Büchi Labortechnik GmbH, Essen, Germany). The aqueous phase was brought to $\mathrm{pH} 7$ and was extracted with ethyl acetate, and the resulting organic phase was removed. The remaining aqueous phase was brought to $\mathrm{pH} 3$ and was again extracted twice with ethyl acetate. The organic fractions were pooled and evaporated to dryness, were resuspended in methanol and centrifuged for $10 \mathrm{~min}$ at $13,000 \times \mathrm{g}$, and the supernatant was again evaporated to dryness. The sample was taken up in $100 \mu \mathrm{l}$ of ethyl acetate and was subsequently methylated with freshly prepared diazomethane (Cohen 1984). Gas chromatographic-mass spectrometry analysis was carried out on a Varian Saturn 2100 ion-trap mass spectrometer, using electron impact ionization at $70 \mathrm{eV}$, connected to a Varian $\mathrm{CP}$ 3900 gas chromatograph equipped with a CP-8400 autosampler (Varian, Darmstadt, Germany). From a 50- $\mu$ l sample in ethyl acetate, $2.5 \mu \mathrm{l}$ were injected in the splitless mode (splitter opening 1:100 after $1 \mathrm{~min}$ ) onto a Phenomenex ZB-5 column (Aschaffenburg, Germany), $30 \mathrm{~m} \times 0.25 \mathrm{~mm} \times 0.25 \mu \mathrm{m}$, using helium carrier gas at the rate of $1 \mathrm{ml} \mathrm{min}^{-1}$. Injector temperature was $250^{\circ} \mathrm{C}$, and the temperature program was $60^{\circ} \mathrm{C}$ for $1 \mathrm{~min}$, followed by an increase of $25^{\circ} \mathrm{C}$ per min to $180^{\circ} \mathrm{C}$, $5^{\circ} \mathrm{C}$ per min to $250^{\circ} \mathrm{C}, 25^{\circ} \mathrm{C}$ per min to $280^{\circ} \mathrm{C}$, and then, $5 \mathrm{~min}$ isothermically at $280^{\circ} \mathrm{C}$. Transfer line temperature was $280^{\circ} \mathrm{C}$, and the trap temperature was $200^{\circ} \mathrm{C}$. IAA was identified by its mass spectrum, monitoring the molecular ion with $\mathrm{m} / \mathrm{z} 189$ and the quinolinium ion with $\mathrm{m} / \mathrm{z} 130$. For the determination of endogenous free IAA levels, approximately $100 \mathrm{mg}$ of fresh weight was extracted as described above, but $100 \mathrm{ng}$ of ${ }^{13} \mathrm{C}_{6^{-}}$ IAA (Cambridge Isotope Laboratories, Andover, MA, U.S.A.) was added as internal standard. For total IAA analysis, the supernatant of a 100-mg fresh-weight equivalent sample was brought to the aqueous phase and was then hydrolyzed with 7 $\mathrm{M} \mathrm{NaOH}$ at $100^{\circ} \mathrm{C}$ under $\mathrm{N}_{2}$ for $3 \mathrm{~h}$. The hydrolysate was filtered, the $\mathrm{pH}$ brought to 2.5 , and the auxins were extracted twice with equal volumes of ethyl acetate. The organic phase was evaporated, and the extract was methylated as described above. Free and total IAA were calculated according to the principles of isotope dilution (Cohen et al. 1986) in the $\mu$ SIS mode for higher sensitivity (Varian manual; Wells and Huston 1995), using the ions at $\mathrm{m} / \mathrm{z} 130$ and 136 deriving from endogenous and ${ }^{13} \mathrm{C}_{6}$-IAA, respectively. The amount of conjugated IAA was calculated by subtraction of the values for free IAA from those of total IAA.

\section{Cytokinin quantification.}

For quantitative analysis, the separation method was modified as follows (Novák et al. 2003). Aliquots of freeze-dried fungal material (100 to $500 \mathrm{mg}$ ) were processed, adding the following internal standards at the extraction stage in $70 \%$ cold ethanol (vol/vol): trans $-\left[{ }^{2} \mathrm{H}_{5}\right]$ zeatin, cis- $\left[{ }^{13} \mathrm{C}_{5}\right]$ zeatin; trans$\left[{ }^{2} \mathrm{H}_{5}\right]$ zeatin riboside, trans- $\left[{ }^{2} \mathrm{H}_{5}\right]$ zeatin-9-glucoside, $\left[{ }^{2} \mathrm{H}_{3}\right]$ dihydrozeatin, $\left[{ }^{2} \mathrm{H}_{3}\right]$ dihydrozeatin riboside, $\left[{ }^{2} \mathrm{H}_{3}\right]$ dihydrozeatin-9glucoside, $\left[{ }^{2} \mathrm{H}_{7}\right]$ dihydrozeatin- $\mathrm{O}$-glucoside, $\left[{ }^{2} \mathrm{H}_{7}\right]$ dihydrozeatin$O$-glucoside riboside $\left[{ }^{2} \mathrm{H}_{6}\right]$ isopentenyladenine, $\left[{ }^{2} \mathrm{H}_{6}\right]$ isopentenyladenine riboside, $\left[{ }^{2} \mathrm{H}_{6}\right]$ isopentenyladenine 9-glucoside, trans$\left[{ }^{2} \mathrm{H}_{5}\right]$ zeatin- $O$-glucoside, trans $-\left[{ }^{2} \mathrm{H}_{5}\right]$ zeatin- $O$-glucoside riboside, trans $-\left[{ }^{2} \mathrm{H}_{5}\right]$ zeatin riboside-5'-monophosphate, $\left[{ }^{2} \mathrm{H}_{3}\right]$ dihydrozeatin riboside-5'-monophosphate, $\left[{ }^{2} \mathrm{H}_{6}\right]$ isopentenyladenosine5'-monophosphate, $\left[{ }^{2} \mathrm{H}_{7}\right]$ benzyladenine, $\left[{ }^{2} \mathrm{H}_{7}\right]$ benzyladenosine, $\left[{ }^{2} \mathrm{H}_{7}\right]$ benzyladenine-9-glucoside, $\left[{ }^{2} \mathrm{H}_{7}\right]$ benzyladenosine-5'-monophosphate, $\quad\left[{ }^{15} \mathrm{~N}_{4}\right]$ meta-topolin, and $\left[{ }^{15} \mathrm{~N}_{4}\right]$ ortho-topolin. (OlChemIm Ltd, Olomouc, Czech Republic). All topolins were analyzed using internal deuterium standards for $\left[{ }^{15} \mathrm{~N}_{4}\right] \mathrm{mT}$ and $\left[{ }^{15} \mathrm{~N}_{4}\right] \mathrm{oT}$, as no other labeled standards were available.

The combined supernatants were concentrated to approximately $1.0 \mathrm{ml}$ by rotary evaporation under vacuum at $35^{\circ} \mathrm{C}$. The samples were diluted to $20 \mathrm{ml}$ with ammonium acetate buffer $(40 \mathrm{mM}, \mathrm{pH} 6.5)$. The extracts were purified using a combined DEAE-Sephadex (Sigma-Aldrich, St. Louis) $(1.0 \times$ $5.0 \mathrm{~cm})$ octadecylsilica $(0.5 \times 1.5 \mathrm{~cm})$ column and immunoaffinity chromatography (IAC), based on wide-range specific monoclonal antibodies against cytokinins (Faiss et al. 1997). This resulted in three fractions: i) the free bases and 9-glycosides (fraction B), ii) a nucleotide fraction, and iii) an $O$-glucoside fraction. The last two fractions were also purified by immunoaffinity chromatography, the second fraction after pretreatment with alkaline phosphatase and the third fraction after treatment with $\beta$-glucosidase. The metabolic eluates from the IAC columns were evaporated to dryness and were dissolved in $20 \mu \mathrm{l}$ of the mobile phase used for quantitative analysis. The samples were subjected to high-pressure liquid chromatography on a reversed-phase column $(150 \mathrm{~mm} \times 2.1 \mathrm{~mm}$; particle size, $5 \mu \mathrm{m}$ ) (Symmetry $\mathrm{C}_{18}$; Waters, Milford, MA, U.S.A.) operated at $30^{\circ} \mathrm{C}$. The components of the eluent were $15 \mathrm{mM}$ ammonium formate, $\mathrm{pH} 4.0$ (A), and methanol (B). They were 
mixed as follows (difference to $100 \%$ is A): $0 \mathrm{~min}, 10 \% \mathrm{~B}, 0$ to $25 \mathrm{~min}$, linear gradient to $50 \% \mathrm{~B}, 25$ to $30 \mathrm{~min}, 50 \% \mathrm{~B}, 30$ to $35 \mathrm{~min}, 100 \% \mathrm{~B}$, all at a flow rate of $250 \mu \mathrm{l}$ per min. Using post-column splitting (1:1), the eluent was simultaneously introduced into a diode array detector (Waters PDA 996), and the electrospray source (source temperature, $100^{\circ} \mathrm{C}$; capillary voltage, $+3.0 \mathrm{kV}$; cone voltage, $+20 \mathrm{~V}$; desolvation temperature, $250^{\circ} \mathrm{C}$ ) of a single-stage quadrupole mass spectrometer (ZMD 2000, Micromass, Manchester, U.K.). Nitrogen was used as both the desolvation gas (400 liter $\left.\mathrm{h}^{-1}\right)$ and the cone gas $\left(50\right.$ liter $\left.\mathrm{h}^{-1}\right)$. Quantification was done by single-ion monitoring of the quasimolecular $\left([\mathrm{M}+\mathrm{H}]^{+}\right)$ions of the plant cytokinins and the corresponding deuterated internal standards.

\section{Statistics.}

Statistics were performed by one-way analysis of variance, and the experiments were repeated four times, with values presented with standard error.

\section{ACKNOWLEDGMENTS}

We thank T. Kakimoto (Osaka University) for the gift of the transgenic cytokinin lines, K. Shinozaki (Riken) for the akh2-2tk lines, T. Schmülling (Freie Universität Berlin) for AtCKX lines, J. Imani and K.-H. Kogel (Giessen University) for the mas promoter lines, and the Salk Institute Genomic Analysis Laboratory for providing the sequence-indexed Arabidopsis T-DNA insertion mutants. Work was supported by the SFB 604, a grant from the Deutsche Forschungsgemeinschaft (Oe133/19-1), the Bundesministerium für Bildung and Forschung (IND 03/013), the International Max-Planck Research School Jena, and the Czech Ministry of Education (grant number MSM 6198959216).

\section{LITERATURE CITED}

Abel, S., Nguyen, M. D., and Theologis, A. 1995. The PS-IAA4/5-like family of early auxin-inducible mRNAs in Arabidopsis thaliana. J. Mol. Biol. 251:533-549.

Barazani, O., Benderoth, M., Groten, K., Kuhlemeier, C., and Baldwin, I. T. 2005. Piriformospora indica and Sebacina vermifera increase growth performance at the expense of herbivore resistance in Nicotiana attenuata. Oecologia 146:234-243.

Barker, S. J., and Tagu, D. 2000. The roles of auxins and cytokinins in mycorrhizal symbioses. J. Plant Growth Regul. 19:144-154.

Bartel, B., and Fink, G. R. 1995. ILR1, an amidohydrolase that releases active indole-3-acetic acid from conjugates. Science 268:1745-1748.

Bassil, N. V., Mok, D., and Mok, M. C. 1993. Partial purification of a cistrans-isomerase of zeatin from immature seed of Phaseolus vulgaris L. Plant Physiol. 102:867-872.

Bennett, R. N., Wenke, T., Freudenberg, B., Mellon, F. A., and LudwigMüller, J. 2005. The $t u 8$ mutation of Arabidopsis thaliana encoding a heterochromatin protein 1 homolog causes defects in the induction of secondary metabolite biosynthesis. Plant Biol. 4:348-57.

Binns, A. N. 1994. Cytokinin accumulation and action: Biochemical, genetic and molecular approaches. Annu. Rev. Plant Physiol. Plant Mol. Biol. 45:173-196.

Brandstatter, I., and Kieber, J. J. 1998. Two genes with similarity to bacterial response regulators are rapidly and specifically induced by cytokinin in Arabidopsis. Plant Cell 10:1009-1019.

Bütehorn, B., Rhody, D., and Franken, P. 2000. Isolation and characterization of Pitef1 encoding the translation elongation factor EF-1 $\alpha$ of the root endophyte Piriformospora indica. Plant Biol. 2:687-692.

Cohen, J. D. 1984. Convenient apparatus for the generation of small amounts of diazomethane. J. Chromatogr. 303:193-196.

Cohen, J. D., Baldi, B. G., and Slovin, J. P. $1986 .{ }^{13} \mathrm{C}_{6}$-[benzene ring]-Indole-3-acetic acid. Plant Physiol. 80:14-19.

Comai, L., Moran, P., and Maslyar, D. 1990. Novel and useful properties of a chimeric plant promoter combining CaMV 35S and MAS elements. Plant Mol. Biol. 15:373-381.

Cooper, J. B., and Long, S. R. 1994. Morphogenetic rescue of Rhizobium meliloti nodulation mutants by trans-zeatin secretion. Plant Cell 6:215225.

Davies, P. J. 2004. The plant hormones: Their nature, occurrence and function, Pages 1-15 in: Plant Hormones: Biosynthesis, Signal Transduction, Action, P. J. Davies, ed. Kluwer Academic Publishers, Dordrecht, The Netherlands.
Faiss, M., Zalubìlová, J., Strnad, M., and Schmülling, T. 1997. Conditional transgenic expression of the ipt gene indicates a function for cytokinins in paracrine signaling in whole tobacco plants. Plant J. 12:401-415.

Fitze, D., Wiepning, A., Kaldorf, M., and Ludwig-Müller, J. 2005. Auxins in the development of an arbuscular mycorrhizal symbiosis in maize. J. Plant Physiol. 162:1210-1219.

Fukaki, H., Okushima, Y., and Tasaka, M. 2007. Auxin-mediated lateral root formation in higher plants. Int. Rev. Cytol. 256:111-137.

Ginzberg, I., David, R., Shaul, O., Elad, Y., Winiger, S., Ben-Dor, B., Badani, H., Fang, Y, von Rhijn, P., Li, Y., Hirsch, A. M., and Kapulnik, Y. 1998. Glomus intraradices colonization regulates gene expression in tobacco roots. Symbiosis 25:145-157.

Gil, P., Lin, Y., Orbovic, V., Verkamp, E., Poft, K. L., and Green, P. J. 1994. Characterization of the auxin-inducible SAUR-AC1 gene for use as a molecular genetic tool in Arabidopsis. Plant Physiol. 104:777784.

Glen, M., Tommerup, I. C., Bougher, N. L., and O'Brien, P. A. 2002. Are Sebacinaceae common and widespread ectomycorrhizal associates of Eucalyptus species in Australian forests? Mycorrhiza 12:243-247.

Goda, H., Sawa, S., Asami, T., Fujioka, S., Shimada, Y., and Yoshida, S. 2004. Comprehensive comparison of auxin-regulated and brassinosteroid-regulated genes in Arabidopsis. Plant Physiol. 134:1555-1573.

Gonzalez-Rizzo, S., Crespi, M., and Frugier, F. 2006. The Medicago truncatula CRE1 cytokinin receptor regulates lateral root development and early symbiotic interaction with Sinorhizobium meliloti. Plant Cell 18:2680-2893.

Guilfoyle, T. J., and Hagen, G. 2007. Auxin response factors. Curr. Opin. Plant Biol. 10:453-460

Herrmann, S., Oelmüller, R., and Buscot, F. 2004. Manipulation of the onset of ectomycorrhiza formation by indole-3-acetic acid, activated charcoal or relative humidity in the association between oak microcuttings and Piloderma croceum: Influence on plant development and photosynthesis. J. Plant Physiol. 161:509-517.

Higuchi, M., Pischke, M. S., Mähönen, A. P., Miyawaki, K., Hashimoto, Y., Seki, M., Kobayashi, M., Shinozaki, K., Kato, T., Tabata, S., Helariutta, Y., Sussman, M. R., and Kakimoto, T. 2004. In planta functions of the Arabidopsis cytokinin receptor family. Proc. Natl. Acad. Sci. U.S.A. 101:8821-8826.

Hillebrand, H., Tiemann, B., Hell, R., Bartling, D., and Weiler, E. W. 1996. Structure of the gene encoding nitrilase 1 from Arabidopsis thaliana. Gene 170:197-200.

Houba-Herin, N., Pethe, C., d'Alayer, J., and Laloue, M. 1999. Cytokinin oxidase from Zea mays: Purification, cDNA cloning and expression in moss protoplasts. Plant J. 17:615-626.

Hwang, I., and Sheen, J. 2001. Two-component circuitry in Arabidopsis cytokinin signal transduction. Nature 413:383-389.

Inoue, T., Higuchi, M., Hashimoto, Y., Seki, M., Kobayashi, M., Kato, T., Tabata, S., Shinozaki, K., and Kakimoto, T. 2001. Identification of CRE1 as a cytokinin receptor from Arabidopsis. Nature 409:1060-1063.

Kakimoto, T. 2001. Identification of plant cytokinin biosynthetic enzymes as dimethylallyl diphosphate:ATP/ADP isopentenyltransferases. Plant Cell Physiol. 42:677-685.

Kakimoto, T. 2003. Perception and signal transduction of cytokinins. Annu. Rev. Plant Biol. 54:605-627.

Kaldorf, M., Koch, B., Rexer, K. H., Kost, G., and Varma, A. 2005. Patterns of interaction between Populus Esch5 and Piriformospora indica: A transition from mutualism to antagonism. Plant Biol. 7:210-218.

Kiba, T., Naitou, T., Koizumi, N., Yamashino, T., Sakakibara, H., and Mizuno, T. 2005. Combinatorial microarray analysis revealing Arabidopsis genes implicated in cytokinin responses through the His- $>$ Asp Phosphorelay circuitry. Plant Cell Physiol. 46:339-355.

Kyozuka J. 2007. Control of shoot and root meristem function by cytokinin. Curr. Opin. Plant Biol. 10:442-446.

Liu, Z. B., Ulmasov, T., Shi, X., Hagen, G., and Guilfoyle, T. J. 1994. Soybean $\mathrm{GH} 3$ promoter contains multiple auxin-inducible elements. Plant Cell 6:645-657.

Liscum, E., and Reed, J. W. 2002. Genetics of Aux/IAA and ARF action in plant growth and development. Plant Mol. Biol. 49:387-400.

Lohar, D. P., Schaff, J. E., Laskey, J. G., Kieber, J. J., Bilyeu, K. D., and Bird, D. M. 2004. Cytokinins play opposite roles in lateral root formation, and nematode and rhizobial symbioses. Plant J. 38:203-14.

Lohrmann, J., and Harter, K. 2002. Plant two-component signaling systems and the role of response regulators. Plant Physiol. 128:363-369.

Ludwig-Müller, J. 1999. The biosynthesis of auxins. Curr. Topics Plant Biol. 1:77-88.

Ludwig-Müller, J. 2000. Hormonal balance in plants during colonization by mycorrhizal fungi. Pages 263-285 in: Arbuscular Mycorrhizas: Physiology and Function, D. D. Douds, and Y. Kapulnik, eds. Kluwer Academic Publishers, Dordrecht, The Netherlands.

Ludwig-Müller, J., Vertocnik, A., and Town, C. D. 2005. Analysis of 
indole-3-butyric acid-induced adventitious root formation on Arabidopsis stem segments. J. Exp. Bot. 56:2095-2105.

Martin, R. C., Mok, M. C., and Mok, D. W. 1999a. Isolation of a cytokinin gene, ZOG1, encoding zeatin O-glucosyltransferase from Phaseolus lunatus. Proc. Natl. Acad. Sci. U.S.A. 96:284-289.

Martin, R. C., Mok, M. C., and Mok, D. W. 1999b. A gene encoding the cytokinin enzyme zeatin $O$-xylosyltransferase of Phaseolus vulgaris. Plant Physiol. 120:553-558.

Martin, R. C., Mok, M. C., Habben, J. E., and Mok, D. W. 2001. A maize cytokinin gene encoding an $\mathrm{O}$-glucosyltransferase specific to $\mathrm{cis}$-zeatin Proc. Natl. Acad. Sci. U.S.A. 98:5922-5926.

Mikkelsen, M. D., Naur, P., and Halkier, B. A. 2004. Arabidopsis mutants in the C-S lyase of glucosinolate biosynthesis establish a critical role for indole-3-acetaldoxime in auxin homeostasis. Plant J. 37:770-777.

Miyawaki, K., Tarkowski, P., Matsumoto-Kitano, M., Kato, T., Sato, S., Tarkowska, D., Tabata, S., Sandberg, G., and Kakimoto, T. 2006. Roles of Arabidopsis ATP/ADP isopentenyltransferases and tRNA isopentenyltransferases in cytokinin biosynthesis. Proc. Natl. Acad. Sci. U.S.A. 103:16598-16603

Mok, D. W., and Mok, M. C. 2001. Cytokinin metabolism and action. Annu. Rev. Plant Physiol. Plant Mol. Biol. 52:89-118.

Moon, Y. H., Chen, L., Pan, R. L., Chang, H. S., Zhu, T., Maffeo, D. M., and Sung, Z. R. 2003. EMF genes maintain vegetative development by repressing the flower program in Arabidopsis. Plant Cell 15:681-693.

Morris, R. O., Bilyeu, K. D., Laskey, J. G., and Cheikh, N. N. 1999. Isolation of a gene encoding a glycosylated cytokinin oxidase from maize. Biochem. Biophys. Res. Commun. 255:328-333.

Murashige, T., and Skoog, F. 1962. A revised medium for rapid growth and bioassays with tobacco tissue cultures. Physiol. Plant. 15:473-497.

Murray, J. D., Karas, B. J., Sato, S., Tabata, S., Amyot, L., and Szczyglowski, K. 2007. A cytokinin perception mutant colonized by Rhizobium in the absence of nodule organogenesis. Science 315:101104.

Nishimura, C., Ohashi, Y., Sato, S., Kato, T., Tabata, S., and Ueguchi, C. 2004. Histidine kinase homologs that act as cytokinin receptors possess overlapping functions in the regulation of shoot and root growth in Arabidopsis. Plant Cell 16:1365-1377.

Novák, O., Tarkowski, P., Tarkowská, D., Doležal, K., Lenobel, R., and Strand, M. 2003. Quantitative analysis of cytokinins in plants by liquid chromatography-single-quadrupole mass spectrometry. Anal. Chim. Acta 480:207-218.

Oelmüller, R., Shahollari, B., Peškan-Berghöfer, T., Trebicka, A., Giong, P. H., Sherameti, I., Oudhoff, M., Venus, Y., Altschmied, L., and Varma, A. 2004. Molecular analyses of the interaction between Arabidopsis roots and the growth-promoting fungus Piriformospora indica. Endocytobiosis Cell Res. 15:504-517.

Oelmüller, R., Peškan-Berghöfer, T., Shahollari, B., Sherameti, I., and Varma, A. 2005. MATH-domain containing proteins represent a novel gene family in Arabidopsis thaliana and are involved in plant/microbe interactions. Phys. Plant. 124:152-166.

Oldroyd, G. E. 2007. Nodules and hormones. Science 315:52-53

Peškan-Berghöfer, T., Shahollari, B., Giang, P. H., Hehl, S., Markert, C., Blanke, V., Varma, A. K., and Oelmüller, R. 2004. Association of Piriformospora indica with Arabidopsis thaliana roots represents a novel system to study beneficial plant-microbe interactions and involves early plant protein modifications in the endoplasmatic reticulum and at the plasma membrane. Physiol. Plant. 122:465-477.

Pfalz, J., Liere, K., Kandlbinder, A., Dietz, K. J., and Oelmüller, R. 2006. pTAC2, -6 , and -12 are components of the transcriptionally active plastid chromosome that are required for plastid gene expression. Plant Cell 18:176-197.

Pham, G. H., Kumari, R., Singh, A., Sachdev, M., Prasad, R., Kaldorf, M., Buscot, F., Oelmüller, R., Peškan, T., Weiss, M., Hampp, R., and Varma, A. 2004. Axenic cultures of Piriformospora indica. Pages 593 616 in: Plant Surface Microbiology. A. Varma, L. Abbott, D. Werner, and R. Hampp, eds. Springer-Verlag, Berlin.

Quint, M., and Gray, W. M. 2006. Auxin signaling. Curr. Opin. Plant Biol. 9:448-453.

Rahman, A, Bannigan, A, Sulaman, W, Pechter, P, Blancaflor, E. B., and Baskin, T. I. 2007. Auxin, actin and growth of the Arabidopsis thaliana primary root. Plant J. 50:514-528.

Rai, M. K., Varma, A., and Pandey, A. K. 2004. Antifungal potential of Spilanthes calva after inoculation of Piriformospora indica. Mycoses 47:479-481.

Reddy, S. M., Hitchin, S., Melayah, D., Pandey, A. K., Raffier, C., Henderson, J., Marmeisse, R., and Gay, G. 2006. The auxin-inducible GH3 homologue Pp-GH3.16 is downregulated in Pinus pinaster root systems on ectomycorrhizal symbiosis establishment. New Phytol. 170:391-400.

Riefler, M., Novak, O., Strnad, M., and Schmülling, T. 2006. Arabidopsis cytokinin receptor mutants reveal functions in shoot growth, leaf senescence, seed size, germination, root development, and cytokinin metabolism. Plant Cell 18:40-54.

Sahay, N. S., and Varma, A. 1999. Piriformospora indica: A new biological hardening tool for micropropagated plants. FEMS (Fed. Eur. Microbiol. Soc.) Lett. 181:297-302.

Sakakibara, H. 2006. Cytokinins: Activity, biosynthesis, and translocation. Annu. Rev. Plant Biol. 57:431-449.

Sawa, S., Ohgishi, M., Goda, H., Higuchi, K., Shimada, Y., Yoshida, S., and Koshiba, T. 2002. The HAT2 gene, a member of the HD-Zip gene family, isolated as an auxin inducible gene by DNA microarray screening, affects auxin response in Arabidopsis. Plant J. 32:1011-1022.

Selosse, M. A., Bauer, R., and Moyersoen, B. 2002a. Basal hymenomycetes belonging to the Sebacinaceae are ectomycorrhizal on temperate deciduous trees. New Phytol. 155:183-195.

Selosse, M. A., Weiss, M., Jany, J. L., and Tillier, A. 2002b. Communities and populations of sebacinoid basidiomycetes associated with the achlorophyllous orchid Neottia nidus-avis (L.) L.C.M. Rich., and neighbouring tree ectomycorrhizae. Mol. Ecol. 11:1831-1844.

Shahollari, B., Varma, A., and Oelmüller, R. 2005. Expression of a receptor kinase in Arabidopsis roots is stimulated by the basidiomycete Piriformospora indica and the protein accumulates in Triton X-100 insoluble plasma membrane microdomains. J. Plant Physiol. 162:945-958.

Shahollari, B., Vadassery, J., Varma, A., and Oelmüller, R. 2007. A leucine-rich repeat protein is required for growth promotion and enhanced seed production mediated by the endophytic fungus Piriformospora indica in Arabidopsis thaliana. Plant J. 50:1-13.

Sherameti, I., Sopory, S. K., Trebicka, A., Pfannschmidt, T., and Oelmüller, R. 2002. Photosynthetic electron transport determines nitrate reductase gene expression and activity in higher plants. J. Biol. Chem. 277:46594-46600.

Sherameti, I., Shahollari, B., Landsberger, M., Westermann,M., Cherepneva, G., Kusnetsov, V., and Oelmüller, R. 2004. Cytokinin stimulates polyribosome loading of nuclear-encoded mRNAs for the plastid ATP synthase in etioplasts of Lupinus luteus: The complex accumulates in the inner-envelope membrane with the $\mathrm{CF}(1)$ moiety located towards the stromal space. Plant J. 38:578-593.

Sherameti, I., Shahollari, B., Venus, Y., Altschmied, L., Varma, A., and Oelmüller, R. 2005. The endophytic fungus Piriformospora indica stimulates the expression of nitrate reductase and the starch-degrading enzyme glucan-water dikinase in tobacco and Arabidopsis roots through a homeodomain transcription factor which binds to a conserved motif in their promoters. J. Biol. Chem. 280:2641-2647.

Sherameti, I., Tripathi, S., Varma, A., and Oelmüller, R. 2008a. The rootcolonizing endophyte Pirifomospora indica confers drought tolerance in Arabidopsis by stimulating the expression of drought stress-related genes in leaves. Mol. Plant-Microbe Interact. 21:799-807.

Sherameti, I., Venus, Y., Drzewiecki, C., Tripathi, S., Dan, V. M., Nitz, I., Varma, A., Grundler, F. M., and Oelmüller, R. 2008b. PYK10, a $\beta$-glucosidase located in the endoplasmatic reticulum, is crucial for the beneficial interaction between Arabidopsis thaliana and the endophytic fungus Piriformospora indica. Plant J. 21:799-807.

Seidel, C., Walz, A., Park, S., Cohen, J. D., and Ludwig-Müller, J. 2006. Indole-3-acetic acid protein conjugates: Novel players in auxin homeostasis. Plant Biol. 8:340-345.

Siemens, J., Keller, I., Sarx, J., Kunz, S., Schuller, A., Nagel, W., Schmülling, T., Parniske, M., and Ludwig-Müller, J. 2006. Transcriptome analysis of Arabidopsis clubroots and disease resistance of cytokinin oxidase/dehydrogenase gene overexpressing plants indicate a key role for cytokinin in disease development. Mol. Plant-Microbe Interact. 19:480-494.

Sirrenberg, A., Göbel, C., Grond, S., Czempinski, N., Ratzinger A., Karlovsky, P., Santos, P., Feussner, I., and Pawlowski, K. 2007. Piriformospora indica affects plant growth by auxin production. Physiol. Plant 131:581-589.

Spíchal, L., Rakova, N.Y., Riefler. M., Mizuno, T., Romanov, G. A., Strnad, M., and Schmülling, T. 2004. Two cytokinin receptors of Arabidopsis thaliana, CRE1/AHK4 and AHK3, differ in their ligand specificity in a bacterial assay._Plant Cell Physiol. 45:1299-1305.

Staswick, P. E., Serban, B., Rowe, M., Tiryaki, I., Maldonado, M. T., Maldonado, M. C., and Suza, W. 2005. Characterization of an Arabidopsis enzyme family that conjugates amino acids to indole-3-acetic acid. Plant Cell 17:616-627.

Suttle, J. C., and Banowetz, G. M. 2000. Changes in cis-zeatin and ciszeatin riboside and biological activity during tuber dormancy. Physiol. Plant 109:68-74.

Takei, K., Sakakibara, H., and Sugiyama, T. 2001. Identification of genes encoding adenylate isopentenyltransferase, a cytokinin biosynthesis enzyme, in Arabidopsis thaliana. J. Biol. Chem. 276:26405-26410.

Tan, X., Calderon-Villalobos, L. I., Sharon, M., Zheng, C., Robinson, C. 
V., Estelle, M., and Zheng, N. 2007. Mechanism of auxin perception by the TIR1 ubiquitin ligase. Nature 446:640-645.

Tian, Q., Uhlir, N. J., and Reed, J. W. 2002. Arabidopsis SHY2/IAA3 inhibits auxin-regulated gene expression. Plant Cell 14:301-319.

Tirichine, L., Sandal, N., Madsen, L. H., Radutoiu, S., Albrektsen, A. S., Sato, S., Asamizu, E., Tabata, S., and Stougaard, J. 2007. A gain-offunction mutation in a cytokinin receptor triggers spontaneous root nodule organogenesis. Science 315:104-107.

Ueguchi, C., Sato, S., Kato, T., and Tabata, S. 2001. The AHK4 gene involved in the cytokinin-signaling pathway as a direct receptor molecule in Arabidopsis thaliana. Plant Cell Physiol. 42:751-755.

Ulmasov, T., Liu, Z. B., Hagen, G., and Guilfoyle, T. J. 1995. Composite structure of auxin response elements. Plant Cell 7:1611-1623.

Ulmasov, T., Murfett, J., Hagen, G., and Guilfoyle, T. J. 1997. Aux/IAA proteins repress expression of reporter genes containing natural and highly active synthetic auxin response elements. Plant Cell 9:1963-1971.

Urban, A., Weiss, M., and Bauer, R. 2003. Ectomycorrhizas involving sebacinoid mycobionts. Mycol. Res. 107:3-14.

van Rhijn, P., Fang, Y., Galili, S., Shaul, O., Atzmon, N., Wininger, S., Eshed, Y., Lum, M., Li, Y., To., Y., Fujishige, N., Kapulnik, Y., and Hirsch, A. M. 1997. Expression of early nodulin genes in alfalfa mycorrhizae indicates that signal transduction pathways used in forming arbuscular mycorrhizae and Rhizobium-induced nodules may be conserved. Proc. Natl. Acad. Sci. U.S.A. 94:5467-5472.

Varma, A., Verma, S., Sudha, S., Sahay, N. S., Butehorn, B., and Franken, P. 1999. Piriformospora indica, a cultivable plant growth promoting root endophyte. Appl. Environ. Microbiol. 65:2741-2744.

Varma, A., Singh, A., Sudha, S., Sahay, N., Sharma, J., Roy, A., Kumari, M., Rana, D., Thakran, S., Deka, D., Bharti, K., Franken, P., Hurek, T., Blechert, O., Rexer, K.-H., Kost, G., Hahn, A., Hock, B., Maier, W. Walter, M., Strack, D., and Kranner, I. 2001. Piriformospora indica: A cultivable mycorrhiza-like endosymbiotic fungus. Pages 123-150 in: Mycota IX. B. Bock, ed., Springer Series, Springer-Verlag, Berlin.

Verma, S. A., Varma, A., Rexer, K.-H., Hassel, A., Kost, G., Sarbhoy, A., Bisen, P., Bütehorn, B., and Franken, P. 1998. Piriformospora indica, gen. et sp. nov., a new root-colonizing fungus. Mycologia 90:898-905

Walker, J. C., and Key, J. L. 1982. Isolation of cloned cDNAs to auxinresponsive poly $(\mathrm{A})^{+}$RNAs of elongating soybean hypocotyl. Proc. Natl Acad. Sci. U.S.A. 79:7185-7189.

Waller, F., Achatz, B., Baltruschat, H., Fodor, J., Becker, K., Fischer, M., Heier, T., Huckelhoven, R., Neumann, C., von Wettstein, D., Franken, P., and Kogel, K.H. 2005. The endophytic fungus Piriformospora indica reprograms barley to salt-stress tolerance, disease resistance, and higher yield. Proc. Natl. Acad. Sci. U.S.A. 102:13386-13391.

Weiss, M., Selosse, M. A., Rexer, K. H., Urban, A., and Oberwinkler, F. 2004. Sebacinales: A hitherto overlooked cosm of heterobasidiomycetes with a broad mycorrhizal potential. Mycol. Res. 108:1003-1010.

Wells, G., and Huston, C. 1995. High-resolution selected ion monitoring in a quadrupole ion trap mass spectrometer. Anal. Chem. 67:3650-3655.

Werner, T., Köllmer, I., Bartrina, I., Holst, K., and Schmülling, T. 2006. New insights into the biology of cytokinin degradation. Plant Biol. 8:371-381.

Werner, T., Motyka, V., Laucou, V., Smets, R., Van Onckelen, H., and Schmülling, T. 2003. Cytokinin-deficient transgenic Arabidopsis plants show multiple developmental alterations indicating opposite functions of cytokinins in the regulation of shoot and root meristem activity. Plant Cell 15:2532-2550.

Werner, T., Motyka, V., Strnad, M., and Schmülling, T. 2001. Regulation of plant growth by cytokinin. Proc. Natl. Acad. Sci. U.S.A. 98:1048710492.

Woodward, A. W., and Bartel, B. 2005. A receptor for auxin. Plant Cell 17:2425-2429.

Yonekura-Sakakibara, K., Kojima, M., Yamaya, T., and Sakakibara, H. 2004. Molecular characterization of cytokinin-responsive histidine kinases in maize. Differential ligand preferences and response to ciszeatin. Plant Physiol. 134:1654-1361.

Zhao, Y., Hull, A. K., Gupta, N. R., Goss, K. A., Alonso, J., Ecker, J. R., Normanly, J., Chory, J., and Celenza, J. L. 2002. Trp-dependent auxin biosynthesis in Arabidopsis: Involvement of cytochrome P450s CYP79B2 and CYP79B3. Genes Dev. 16: 3100-3112. 